\title{
Synthesis and Fluorescence Mechanism of the Aminoimidazolone Analogues of the Green Fluorescent Protein: Towards Advanced Dyes with Enhanced Stokes Shift, Quantum Yield and Two-Photon Absorption
}

\author{
Ervin Kovács ${ }^{+}{ }^{[a, b]}{\text { Levente } \text { Cseri }^{+},{ }^{[a, c]} \text { Attila Jancsó, }}^{[d]}$ Ferenc Terényi, ${ }^{[d]}$ Anna Fülöp, ${ }^{[a]}$ \\ Balázs Rózsa, ${ }^{[\mathrm{e}, \mathrm{f]}}$ Gábor Galbács, ${ }^{[\mathrm{d}]}$ and Zoltán Mucsi*[a, g] \\ In memory of Ferenc Fülöp
}

Novel small-molecular analogues the green fluorescence protein (GFP) chromophore were synthesised to expand and improve this fluorophore family and to deepen the understanding of their fluorescence mechanism. The introduction of an aminophenyl substituent and the repositioning of the hydroxyl group, to enable strong intramolecular hydrogen bonding, not only enhanced fluorescence emission but also resulted in an increased Stokes shift and a considerable redshift. Experimental and computational results described dual fluorescence involving both excited-state intramolecular proton transfer and internal charge transfer (ESIPT-ICT) mechanisms.
Screening of the $\mathrm{pH}$ and the solvent medium revealed a complicated equilibrium involving hydrogen bonding, protonation and deprotonation that influences the absorption and emission spectra. Further improvement of the photophysical properties via the systematic variation of dialkylamino substituents at a single position of the chromophore led to a twoorders of magnitude enhancement in the quantum yields. In addition, the novel compounds also have significant twophoton absorption, which widens the possibilities for applications in the field of bioimaging.

\section{Introduction}

The natural green fluorescent protein (GFP) - composed of 238 amino acid residues (ca. $26.9 \mathrm{kDa}$ ) - has been extensively applied in molecular biology, neurobiology and biotechnology as a genetically encoded fluorescent tag. The protein emits green light under blue excitation with a fluorescence quantum yield (QY) as high as $0.8,{ }^{[1]}$ which was originally attributed to its chromophore, 4-(4-hydroxybenzylidene)-1,2-dimethyl-1H-imidazol-5(4H)-one ( $p$-HOBDI; Figure 1). ${ }^{[2]}$ However, stripped of its surrounding protein environment, the fluorescence QY of $p$ HOBDI drops by more than four orders of magnitude compared to the parent protein. Some simple $p$-HOBDI analogues, such as $o$-HOBDI ${ }^{[3]} o-\mathrm{TsABDI}^{[4]} p$-TsABDI, ${ }^{[5]}{ }^{[-\mathrm{AABDI}},{ }^{[6]}$ and $p$-AABDI, ${ }^{[7]}$ also exhibit low $Q Y\left(10^{-2-} 10^{-4}\right)$, and the para-amino analogue of $p$-HOBDI ( $p$-ABDI) is practically non-fluorescent. ${ }^{[8,9]}$ This enormous difference between the small molecule $p$-HOBDI and the GFP has incited intensive research towards the understanding of the fluorescence-quenching mechanism in p-HOBDI and the optimisation of the chromophore structure. ${ }^{[2,10-14]}$ [a] Dr. E. Kovács, ${ }^{+}$Dr. L. Cseri, ${ }^{+}$A. Fülöp, Dr. Z. Mucsi

Department of Chemistry

Femtonics Inc.

Túzoltó u. 58, 1094 Budapest, Hungary

E-mail: kovacs.ervin@ttk.hu zmucsi@femtonics.eu

www.femtonics.eu

[b] Dr. E. Kovács ${ }^{+}$

Institute of Materials and Environmental Chemistry

Research Centre for Natural Sciences

Magyar tudósok körútja 2, 1117 Budapest, Hungary

[c] Dr. L. Cseri

Department of Chemical Engineering \& Analytical Science

The University of Manchester

The Mill, Sackville Street, Manchester, M1 3BB, United Kingdom

[d] Dr. A. Jancsó, F. Terényi, Dr. G. Galbács

Department of Inorganic and Analytical Chemistry

University of Szeged

Dóm tér 8, Szeged 6720, Hungary [e] Dr. B. Rózsa

Two-Photon Measurement Technology Research Group, The Faculty of Information Technology

Pázmány Péter Catholic University

Práter u. 50/A, Budapest 1083, Hungary

[f] Dr. B. Rózsa

Laboratory of 3D Functional Imaging of Neuronal Networks and Dendritic Integration

Institute of Experimental Medicine

Szigony utca 43, Budapest 1083, Hungary

[g] Dr. Z. Mucsi

Institute of Chemistry, Faculty of Materials Science and Engineering, University of Miskolc,

Egyetem út 1, Miskolc 3515, Hungary

$\left.{ }^{+}\right]$These authors contributed equally to this work.

Supporting information for this article is available on the WWW under https://doi.org/10.1002/ejoc.202101173

Part of the Special Collection in memory of Ferenc Fülöp.

ก () 2021 The Authors. European Journal of Organic Chemistry published by Wiley-VCH GmbH. This is an open access article under the terms of the Creative Commons Attribution License, which permits use, distribution and reproduction in any medium, provided the original work is properly cited. 


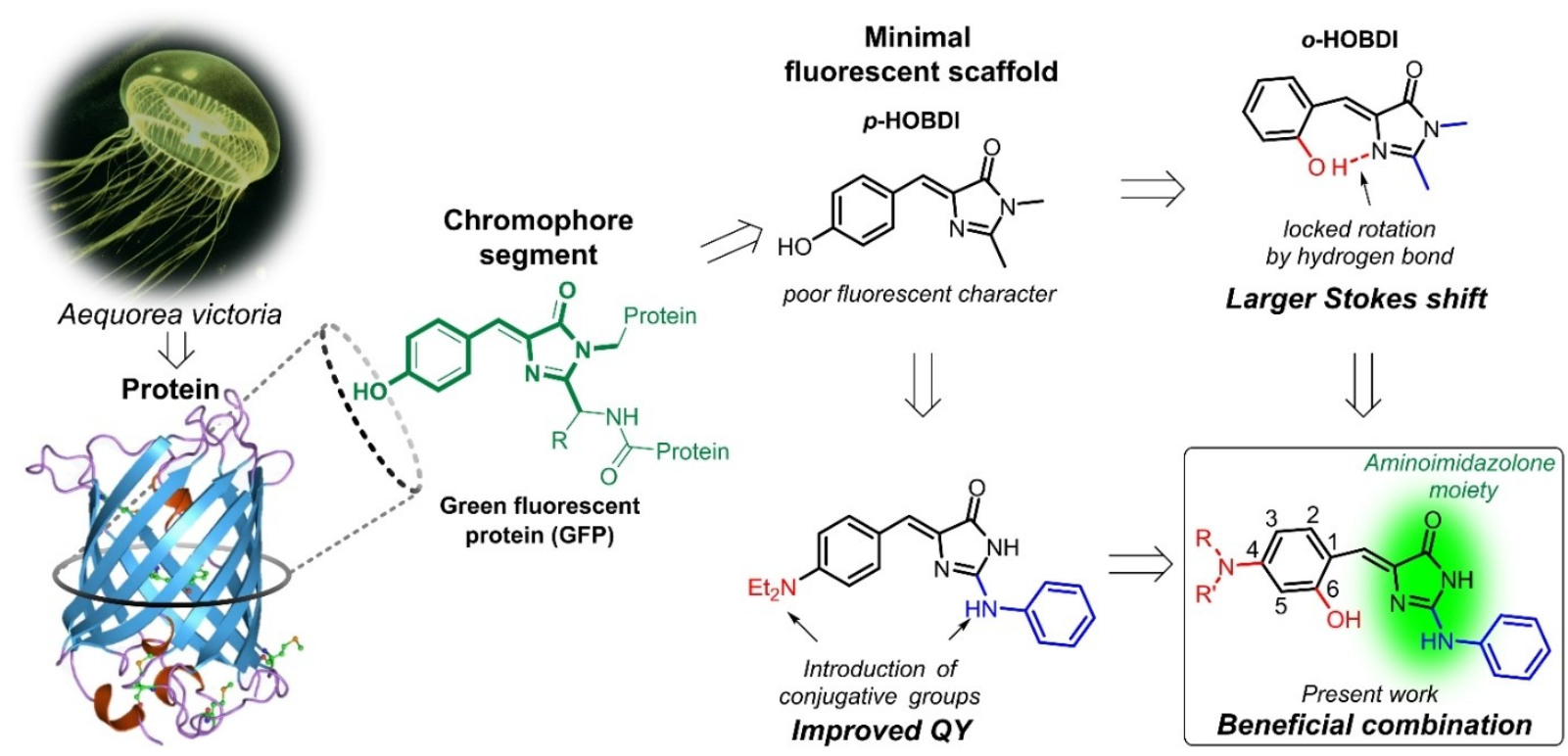

Figure 1. Structure of $p-\mathrm{HOBDI}$, the chromophore of the green fluorescent protein (GFP), and the development strategies to improve its fluorescence properties culminating in the new 2-hydroxy-4-amino-substituted analogues.

These studies revealed the role of the excited state proton transfer (ESPT) from the $p$-hydroxyl group to the Glu222 residue. The resulting excited anion of the chromophore protein segment is perceived to be responsible for the observed intense green fluorescence emission. ${ }^{[10]}$ The protein environment is also known to affect the QY, as well as the emission wavelength, via perturbing the polarity, hydrogen-bonding property, and aromatic $\pi$-interactions of the chromophore, and by creating a strong electric field around it. ${ }^{[10,11]}$ Moreover, it is now known that the barrel-shaped protein environment in natural GFP imposes constrains on the otherwise possible dihedral torsion along the exocyclic $\mathrm{C}=\mathrm{C}$ and $\mathrm{C}-\mathrm{C}$ bonds (the former is possible via photoisomerization). This phenomenon leads to the suppression of the nonradiative decay and consequently, to a largely increased fluorescence emission intensity. ${ }^{[15]}$ This effect is mimicked in several recent studies, which focused on numerous conformationally unrestricted and restricted GFP-like chromophores. ${ }^{[12]}$ Various structurally locked analogues have been synthesized and studied recently to establish strategies for the recovery of the fluorescent intensity in small molecular GFP fluorophore analogues. ${ }^{[16-18]}$

At the same time, the proposed application areas of GFPlike chromophores are rapidly expanding. ${ }^{[19]}$ Fluorescent sensor molecules - utilising the Lewis basic character of the imidazolone nitrogen - showed promising results for the detection of metal ions. ${ }^{[20,21]}$ The unique properties of the GFP fluorophore enabled the development of dyes with aggregation induced emission $^{[22]}$ or temperature induced fluorescent enhancement, ${ }^{[23]}$ and viscosity sensor molecules. ${ }^{[24]}$ GFP-like chromophores have also been applied in bioimaging as fluorescent stains or tags. ${ }^{[19,25-27]}$ However, certain applications have been hindered by the low QY of the basic chromophore. ${ }^{[26]}$ Recent trends in the field of fluorescent imaging show the emergence of two-photon excitation, which makes fluorophores with attractive two-photon fluorescent properties especially sought after. ${ }^{[28]}$ While there are a few studies concerning the two-photon activity of GFP-like chromophores, ${ }^{[29,30]}$ this property has remained mostly unexplored so far despite its practical importance.

Our recent study revealed that the introduction of a conjugative group (e.g. phenylamino group) to the imidazolone ring enables the fluorescence of the para-amino derivatives and it enhances their QY even above that of $p$-HOBDI. ${ }^{[31]}$ The introduction of electron donor substituents into the $p$-HOBDI structure has also been studied to improve the $Q Y$, upshift the emission wavelength and increase the Stokes shift. For instance, the change of the 4-hydroxy group to a 4-diethylamino group on the phenyl ring improved the QY by up to 28 times. $^{[31-33]} \mathrm{An}$ even more remarkable boost in fluorescence is displayed by the amino derivatives in aprotic solvents, out of which the metaamino isomer was shown to have an unusually high, 0.46 QY. ${ }^{[2,13,34]}$ Solvent- and pH-related effects are also often enhanced by the substituents. For example, solvatofluorochromicity is observed in aprotic solvents and hydrogen-bondmediated fluorescence quenching is happening in protic solvents. ${ }^{[2,31]}$ It was also found that ESPT ${ }^{[35]}$ or in certain cases, excited-state intramolecular proton transfer (ESIPT) $)^{[36]}$ and internal charge transfer (ICT) ${ }^{[31]}$ may also play an essential role in determining the fluorescence properties of the planar GFPlike chromophores. Many orthogonal structural modifications of $p$-HOBDI can be found in the literature, also aiming to improve the fluorescence property. ${ }^{[37-44]}$ Alongside the synthetic efforts, an accurate understanding of the fluorescence mechanism must be pursued in order to successfully develop and apply novel fluorophores. 
The present study aims to further improve the fluorescence properties (emission intensity and Stokes shift) of the small-

\begin{tabular}{|c|c|c|c|c|c|}
\hline & $\begin{array}{l}\text { Excitation } \\
\lambda_{\max }(\mathrm{EX}) \\
{[\mathrm{nm}]}\end{array}$ & $\begin{array}{l}\text { Emission } \\
\lambda_{\max }(\mathrm{EM}) \\
{[\mathrm{nm}]}\end{array}$ & $\begin{array}{l}\text { Stokes shift }{ }^{[a]} \\
{[\mathrm{eV}]}\end{array}$ & $\begin{array}{l}\text { Brightness }{ }^{[b]} \\
{\left[\mathrm{M}^{-1} \mathrm{~cm}^{-1}\right]}\end{array}$ & $\mathrm{QY} \mathrm{QY}_{\mathrm{REF}}{ }^{[\mathrm{Cl}}$ \\
\hline $1 \mathrm{a}$ & 374 & 440 & 0.497 & 3.35 & 8.5 \\
\hline $1 b$ & 365 & 438 & 0.566 & 11.0 & 26.1 \\
\hline \multirow[t]{2}{*}{$1 c$} & 380 & 438 & 0.432 & 3.45 & 11.3 \\
\hline & & 564 & 1.064 & 5.75 & 18.7 \\
\hline $1 \mathrm{~d}$ & 375 & 445 & 0.520 & 4.99 & 12.6 \\
\hline $1 \mathrm{e}$ & 428 & 510 & 0.466 & 76.9 & 163.5 \\
\hline $1 \mathrm{f}$ & 438 & 512 & 0.409 & 120 & 226.8 \\
\hline $1 \mathrm{~g}$ & 430 & 512 & 0.462 & 63.6 & 163.6 \\
\hline $1 \mathrm{~h}$ & 417 & 507 & 0.528 & 25.7 & 114.3 \\
\hline $1 \mathrm{i}$ & 459 & 530 & 0.362 & 142 & 241.9 \\
\hline $1 \mathrm{j}$ & 462 & 531 & 0.349 & 143 & 260.8 \\
\hline $1 \mathrm{k}$ & 468 & 548 & 0.387 & 118 & 278.6 \\
\hline 11 & 425 & 553 & 0.675 & 0.557 & 2.1 \\
\hline
\end{tabular}

[a] Stokes shifts are provided as wavelength difference, $\Delta \lambda_{\max }=\lambda_{\max }(\mathrm{EM})-$ $\lambda_{\max }(\mathrm{EX})$, and as eV values. [b] Brightness values are defined as the product of the extinction coefficient $(\varepsilon)$ and the fluorescence quantum yield (QY). [c] Relative quantum yields are given for the reference value of the GFP chromophore $p$ - $\mathrm{HOBDI} \quad\left(\mathrm{QY}_{\mathrm{REF}}=1.6 \times 10^{-5}\right.$ in methanol, determined previously $\left.{ }^{[31]}\right) . \lambda_{\max }$ values are the wavelength positions of absorption and emission maxima.
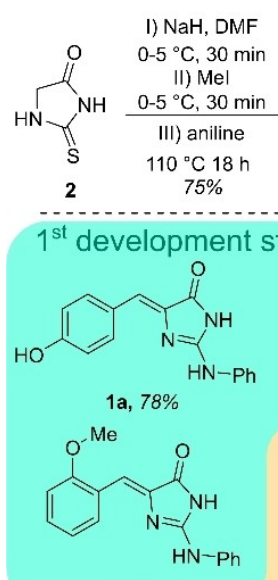

1d, $78 \%$

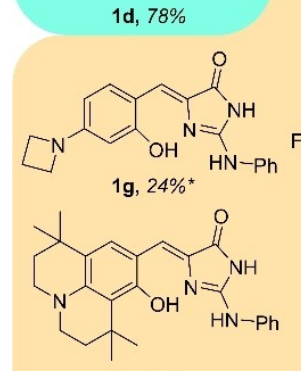

$1 \mathrm{j}, 23 \%$

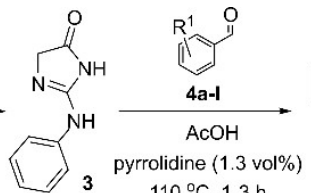
3 pyrrolidine $(1.3 \mathrm{vo})$

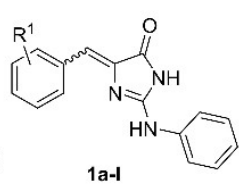

1a-I molecular-weight $p$-HOBDI analogues ${ }^{[45]}$ and to provide a better understanding of the relationship between the observed Stokes shift and the QY of the molecule structure. As a starting scaffold, we used the 2-(phenylamino)-imidazolone derivative of $p$-HOBDI and systematically synthesised and spectroscopically characterised further derivatives by introducing additional electron-donating substituents into the phenyl ring (Figure 1). This molecular design can potentially increase the QY by i) donating further electrons to the $\pi$-system of the phenyl ring, and ii) providing a conformational restraint via hydrogen bonding between a hydroxy substituent at the phenyl ring and the nitrogen of the imidazolone part. ${ }^{[46-49]}$ Furthermore, the two-photon fluorescent properties of the novel compounds are investigated to evaluate their applicability in two-photon bioimaging.

\section{Results and Discussion}

In this study, 10 novel compounds (1 $\mathbf{b}-\mathbf{k}$, listed in Table $\mathbf{1}$ ) were designed and synthesised from 2-thiohydantoin (2) in two-step procedures (Figure 2) to enhance the fluorescent activity of the GFP analogue scaffold $1 \mathrm{a}$. The preceding study revealed the beneficial spectroscopic change of the $\mathrm{OH}$ group at position 4 on the benzylidene phenyl ring. ${ }^{[31]}$ Another work showed significant improvement in the Stokes shift when $\mathrm{OH}$ was placed to position $2 .{ }^{[3]}$ Therefore, in the first development stage, we varied the position of this $\mathrm{OH}$ group around the phenyl ring $(1 \mathrm{a}-\mathrm{c})$ by reacting the intermediate 3 with ortho-, meta- and para-hydroxybenzaldehyde. To investigate the effects of hydrogen bonding and proton transfer in the 2 position, the 2-methoxy analogue $\mathbf{1} \mathbf{d}$ was synthesized identically.

The spectroscopic properties of $\mathbf{1} \mathbf{b}$ - $\mathbf{d}$ in diluted solutions of 1-5 $\mu \mathrm{M}$ in $\mathrm{MeOH}$ were compared to the reference compound 1 a (Table 1 and Table S1), which itself already exhibits enhanced brightness compared to $p$-HOBDI. ${ }^{[31]}$ The UV-Vis spectra of these compounds display absorption peaks between 365 and $380 \mathrm{~nm}$, and a transition centred around $250 \mathrm{~nm}$. All emission spectra exhibit one band with a regular shape, and absorption maxima between $440-560 \mathrm{~nm}$ - with the notable exception of $1 \mathbf{c}$.

The excited state intramolecular proton transfer (ESIPT) mechanism for the 2-hydroxy derivatives of the GFP chromophore was hypothesised earlier. ${ }^{[49-56]}$ Therefore, we investigated the effect of the position of the hydroxyl group on the fluorescence properties. The hydroxyl group at position 3 (1 b) has a small but clear enhancing effect on the emission intensity with little influence on the peak wavelengths of absorption and emission bands. The fluorescence emission of $1 \mathrm{c}(2-\mathrm{OH})$ changes significantly compared to $1 \mathbf{a}(4-\mathrm{OH})$ and $\mathbf{1} \mathbf{b}(3-\mathrm{OH})$. Its spectrum exhibits two emission peaks (Table 1; Figure 3 ), one at the same wavelength ( $438 \mathrm{~nm}$, Stokes shift: $58 \mathrm{~nm}$ or $0.432 \mathrm{eV}$ ) as $1 \mathrm{a}$ and $1 \mathbf{b}$, but also another red-shifted peak (564 nm) which represents an unusually large Stokes shift (184 nm or $1.064 \mathrm{eV}$, Figure 3) with $~ 1.7$-fold larger, enhanced fluorescence emission intensity.
Figure 2. The synthesis of substituted 4-benzylidene-2-(phenylamino)-imidazolones (1 a-l) from 2-(phenylamino)-imidazolone (3) using various aldehydes 4 a-l. *Modified method was used to minimise azetidine ring opening, see Experimental section. 


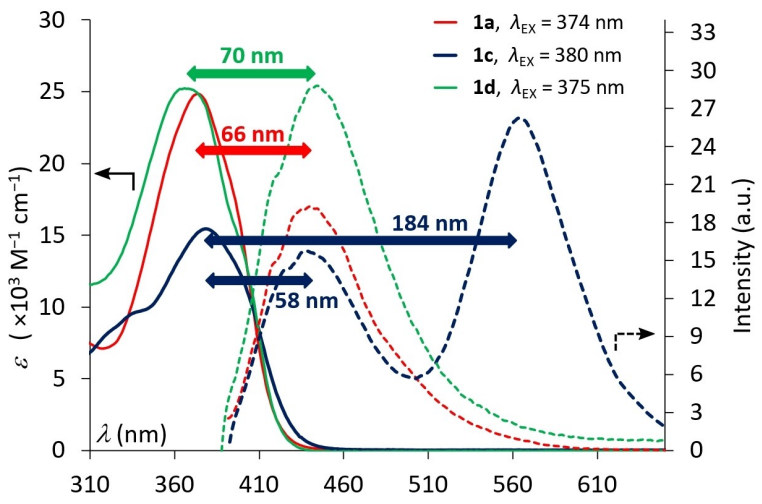

Figure 3. Comparison of the molar UV-Vis absorption and fluorescence emission spectra (intensity values normalised to $c=1.0 \mu \mathrm{M}$ concentrations) of $1 \mathrm{a}$ (red), $1 \mathrm{c}$ (dark blue) and $\mathbf{1} \mathbf{d}$ (green) in methanol. The Stokes shifts of the three compounds are indicated by arrows that have the same colour as the corresponding curves.

The photophysical properties, such as fluorescence emission, of many fluorophores are sensitive to the polarity of the environment. This parameter may influence molecular-scale processes, such as ESIPT, aromatisation, bond strengthening/ weakening or double bond rearrangements. The presence of hydrogen bonds also affects several photophysical and molecular properties. ${ }^{[57,58]}$ Therefore, the spectroscopic properties of $1 \mathrm{c}$ were also studied in more polar (dimethyl sulfoxide (DMSO), MeCN, aqueous 2-[4-(2-hydroxyethyl)piperazin-1-yl]ethane-1sulfonic acid (HEPES) buffer (pH 7.4) with $10 \% \mathrm{MeOH}$ ) and less polar (tetrahydrofuran (THF), dichloromethane (DCM)) solvents in terms of relative permittivity.

The solvent dependence of the UV-Vis absorption and fluorescence emission spectra of $1 \mathrm{c}$ are depicted in Figure 4. The absorption spectra show only a slight variation in terms of the wavelength of the absorption maxima $\left[\lambda_{\max }\right.$ values are between 371 and $386 \mathrm{~nm}$ ]. However, molar absorbances $(\varepsilon)$ vary more with the solvent polarity, especially in the case of $\mathbf{1}$.

There, the $\varepsilon$ value is ca. 1.8 times lower in an aqueous medium (in the presence of $10 \% \mathrm{MeOH}$ ) compared to the value measured in the less polar THF. The fluorescent emission spectra are also dependent on the solvent medium. The lowest intensities were observed in protic solvents, namely in methanol and HEPES buffer. The intensities measured in aprotic solvents were 1-2 orders of magnitude higher with DMSO proving to be the most favourable solvent for the fluorescence. Dual fluorescence was observed except in the case of DCM and THF, where only the higher-wavelength peak is visible. A correlation can be found among the studied solvents, where the position of the emission maximum shifts towards lower wavelengths in the spectrum with the increasing emission intensity.

The effect of $\mathrm{pH}$ on the spectroscopic characteristics of $1 \mathrm{c}$ was also studied in an aqueous medium containing $10 \% \mathrm{MeOH}$. The wavelength of the absorption band - centred at $371 \mathrm{~nm}$ at $\mathrm{pH}=7.40$ - shifts towards higher energies with decreasing $\mathrm{pH}$ $\left(\lambda_{\max }=358 \mathrm{~nm}\right.$ at $\left.\mathrm{pH}=2.50\right)$ while a red shift is observed under alkaline conditions $\left(\lambda_{\max }=407 \mathrm{~nm}\right.$ at $\left.\mathrm{pH}=11.85\right)$ (Figure $\left.5 \mathrm{~A}\right)$.

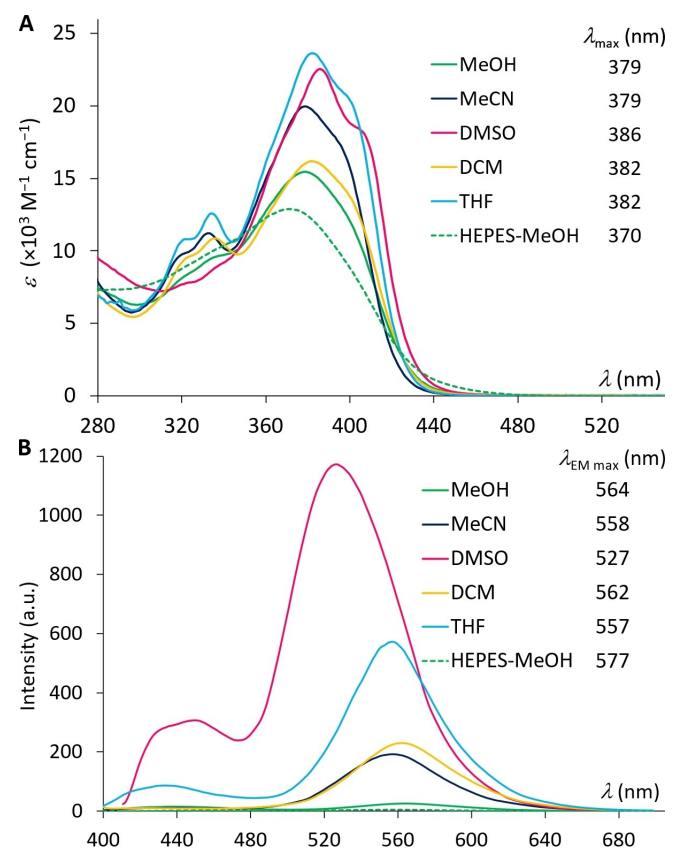

Figure 4. (A) Molar UV-Vis absorption spectra and (B) fluorescence emission spectra, normalised to $c=1.0 \mu \mathrm{M}$ concentration of $1 \mathrm{c}$ in different solvents. Excitations were executed at or near the wavelength position of absorption maxima.

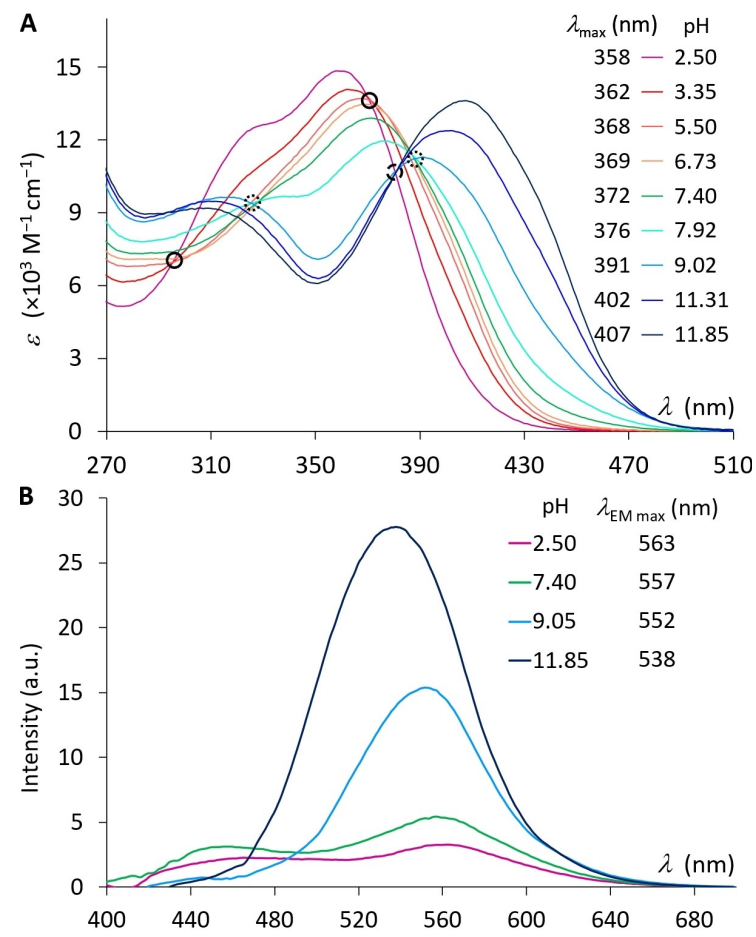

Figure 5. (A) pH-dependent UV-Vis absorption spectra of $1 \mathrm{c}$ in HEPES-MeOH $90-10 \% \mathrm{w} / \mathrm{w}$, normalised to $1.0 \mathrm{M}$ concentrations. The numbers placed at the spectra denote the wavelength of absorption maxima. Clearly distinguishable isosbestic points are encircled. (B) Fluorescence emission spectra of $1 \mathrm{c}$ in HEPES buffer-MeOH $90-10 \% \mathrm{w} / \mathrm{w}$ at different $\mathrm{pH}$ values. Excitation was performed at or near the wavelength position of absorption maxima in the spectra recorded at the same $\mathrm{pH}$ values. 
Examination of the spectra shows several isosbestic points that indicate the operation of $\mathrm{pH}$-dependent equilibria between three or more protonation states of the compound. Similar to the UV-Vis absorption spectra, the wavelengths of the maximum of the emission bands, as well as their intensities significantly differ under acidic and basic conditions (Figure 5B).

At low pH (2.50), both emission bands exist, however, they are shifted by a few nanometres towards higher wavelength values, while their intensities decrease relative to those observed at neutral $\mathrm{pH}$. The increase of $\mathrm{pH}$ results in a more significant shift of the emission band towards lower energies $\left(\lambda_{\mathrm{EM}}=538 \mathrm{~nm}\right)$ accompanied by a remarkable intensity increase (a factor of $\sim 5$ ) relative to the emission intensity at $\mathrm{pH}=7.40$. The most noticeable finding under alkaline conditions is the vanishing of the lower-wavelength emission band at $\mathrm{pH} \geq 9.0$. Compared to the large $\Delta \lambda_{\max }$ value $\left[\lambda_{\max }(\mathrm{EM})-\lambda_{\max }(\mathrm{EX}) \sim 185 \mathrm{~nm}\right]$ found at $\mathrm{pH}=7.40$, the Stokes shift decreases to ca. $110 \mathrm{~nm}$ $(0.642 \mathrm{eV})$. We hypothesise that the characteristic fluorescence properties of $1 \mathrm{c}$ result from the strong internal hydrogen bond ( $\mathrm{HB}$ ) between the $2-\mathrm{OH}$ group and the $-\mathrm{N}=$ atom of the imidazolone ring. The solvent screening results support the parallel ICT and ESIPT mechanisms in the case of $1 \mathrm{c}$ resulting in dual emission. As both strong $\mathrm{HB}$ donor $(\mathrm{MeOH}$ and water) and $\mathrm{HB}$ acceptor (DMSO and THF) solvents can compete with the intramolecular $\mathrm{HB}$ formation, the dominance of the largerStokes-shift band is decreased in the emission spectrum. In DCM and MeCN, the ESIPT mechanism becomes exclusive. The $\mathrm{pH}$ titration experiments also supported the action of the ESIPT mechanism in the case of $1 \mathbf{c}$, as the acidic $\mathrm{pH}$ decreased the Stokes shift significantly, whereas under alkaline conditions the favourable HB form promoted the ESIPT (Figure 6). This assumption of the ESIPT mechanism is further supported by the lack of a similar effect in compound $\mathbf{1} \mathbf{d}$ bearing an OMe group in position 2 (Figure 3, green dotted curve).$^{[40,49]}$ Here, the lack of the acidic $\mathrm{OH}$ group eliminates the ESIPT mechanism and hence, this compound exhibits a Stokes shift value close to those of $1 \mathbf{a}$ and $\mathbf{1} \mathbf{b}$.

In order to shed light on the exact ESIPT mechanism in the studied molecules or the lack of it, systematic computational chemistry calculations for $1 \mathrm{c}$ were performed (Figure 7). The ground state geometry optimisation [M06-2X/6-31G(d,p)//PCM $(\mathrm{MeOH})]$ provided the ground state geometry $(\mathrm{A})$, where the lowest energy conformer $(Z)$ is stabilised by the internal HB. Although, scaffold $1 \mathrm{c}$ can be represented by various resonance structures, here only the lowest energy conformer is represented. Earlier it was shown, that the phenylamino group has a significant electron donating effect, which enhances fluorescence. ${ }^{[31]}$ The $E$ isomer is not the preferred form at room temperature, it readily transforms to the $Z$ isomer. In order to model the excited state, TD-DFT single point calculations and geometry optimisations [TD-M06-2X/6-31G(d,p)//PCM(MeOH)] were carried out. The optimised geometries and energies were obtained for states A-G (Table S2, summarised in Figure 7). When form $A$ absorbs UV light, the Franck-Condon $S_{1}$ excited state is formed as in form B. According to the suggested photochemical process for $1 \mathrm{C}$, after the excitation of the ground state $\left(A \rightarrow B ; 322.9 \mathrm{~kJ} \mathrm{~mol}^{-1}, 394 \mathrm{~nm}, 3.149 \mathrm{eV}\right)$ and the subse-

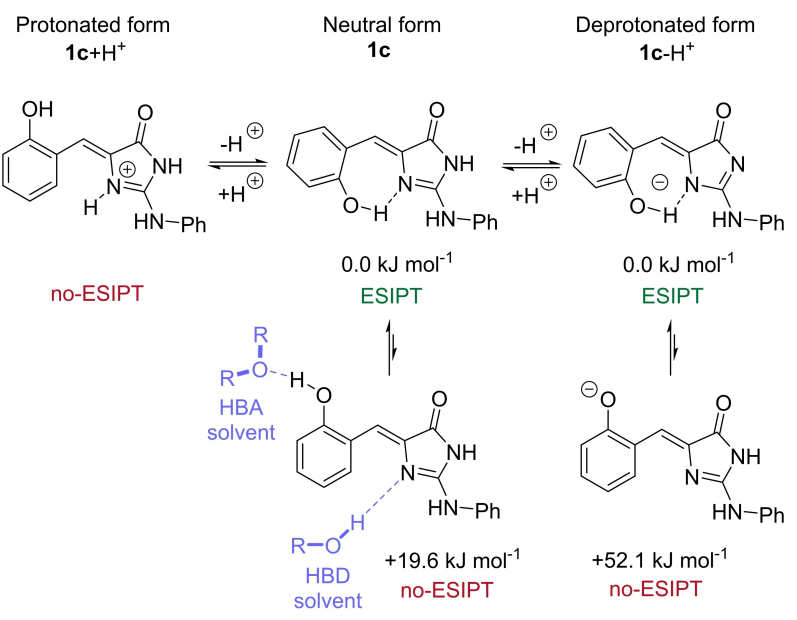

Figure 6. Short summary of the solvent effect (blue), and the proposed structures and protonation states of $1 \mathrm{c}$ on calculated potential energies along with consecutive deprotonation processes in HEPES-MeOH $90-10 \%$ w/w medium calculated at M06-2X/6-31 + $+G(d, p)$ level of theory. HBD: hydrogen bond donor, HBA: hydrogen-bond acceptor.

quent geometric relaxation $\left(B \rightarrow C\right.$; $c$ a. $\left.-26.2 \mathrm{~kJ} \mathrm{~mol}^{-1}\right)$, the excited molecule can either emit a photon $\left(C \rightarrow A^{\prime}\right.$; emission 1 , $263.9 \mathrm{~kJ} \mathrm{~mol}^{-1}, 455 \mathrm{~nm}, 2.725 \mathrm{eV}$ ) or undergo an ESIPT to take a zwitterionic form in the excited state at a lower energy level $\left(C \rightarrow D ;+9.5 \mathrm{~kJ} \mathrm{~mol}^{-1}\right)$. If emission occurred from state $\mathrm{D}$, it would lead to a zwitterionic ground-state intermediate $(D \rightarrow E$, emission 2, $235.4 \mathrm{~kJ} \mathrm{~mol}^{-1}, 508 \mathrm{~nm}, 2.440 \mathrm{eV}$ ), which is inconsistent with the experimental value observed for $1 \mathrm{c}$. State D in this case then can transform back to the initial ground state without an energy barrier $\left(E \rightarrow A, c a .-53.8 \mathrm{~kJ} \mathrm{~mol}^{-1}\right)$ via an internal proton transfer. However, the post-ESIPT state $D$ can further transform to slightly endothermic $\left(+8.5 \mathrm{~kJ} \mathrm{~mol}^{-1}\right)$ structure $\mathrm{F}$ via a low-energy bond rotation, breaking the internal $\mathrm{HB}$. The computed wavelength for emission from state $F$ is $566 \mathrm{~nm}$ $(2.193 \mathrm{eV})$, which agrees well with the experimental value of $1 \mathrm{c}$. $\mathrm{HB}$ donor and acceptor solvents, such as $\mathrm{MeOH}$, are expected to stabilize state $\mathrm{F}$. In light of these computational results, we suggest a complex photochemical process including a joint ESIPT and bond rotation.

The emission peak of $1 \mathrm{c}$ with the larger Stokes shift is attributed to the emission from excited state $F$ to ground state $\mathrm{G}$ at a longer wavelength compared to the process $\mathrm{C} \rightarrow \mathrm{A}$. The $\mathrm{F} \rightarrow \mathrm{G}$ ground state relaxation process is associated with $81.6 \mathrm{~kJ} \mathrm{~mol}^{-1}$ less energy, resulting in the difference of $111 \mathrm{~nm}$ in the two emitted wavelengths 1 and 2.

Even though the dipole moment of $1 \mathrm{c}$ is changed from 7.32 (A) to 14.96 Debye (C) during electronic excitation and geometric relaxation, the total natural bond orbital (NBO) charges of its phenylamino moiety (as an electron donating group) are increased by ca. +0.1 . This absorption process does not involve charge transfer on the basis that it is almost insensitive to solvent polarity (see Table 1). The shapes of the HOMO and LUMO of $1 \mathrm{c}-\mathrm{A}, 1 \mathrm{c}-\mathrm{C}$ and $1 \mathrm{c}-\mathrm{D}$ are indicating similar electron distributions (Figure 10). Changes in the HOMO and LUMO shapes during the excitation process are not significant; 


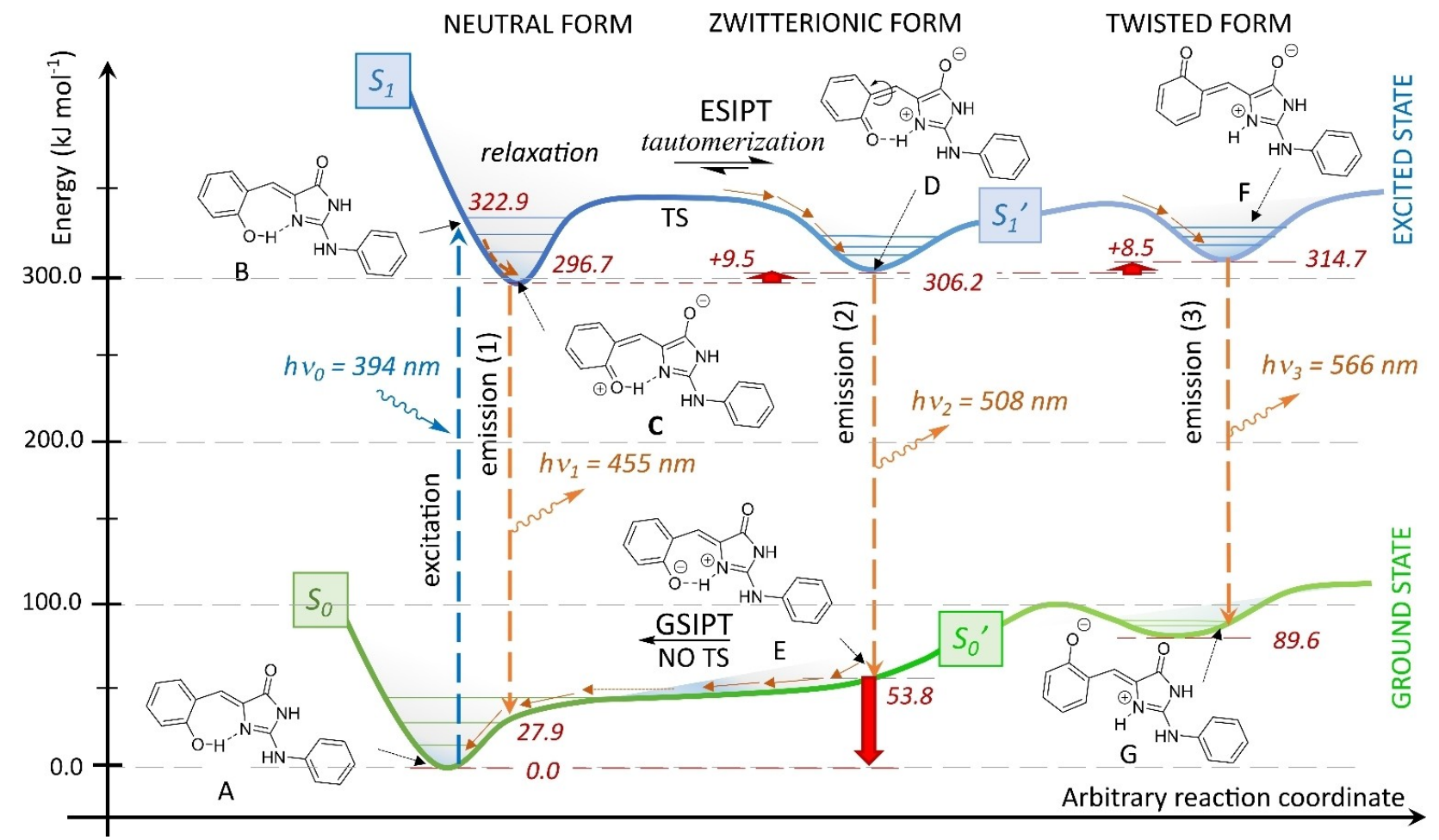

Figure 7. Schematic illustration of the excitation -emission photochemical cycle for compound $1 \mathrm{c}$. After the excitation of compound $1 \mathrm{c}-\mathrm{A}$ (ground state, $\mathrm{S}_{0}$ surface), structure $B$ at the $S_{1}$ state relaxes to the energy minimum (C). The excited molecule (C) can return to the ground state (A) by emitting a shortwavelength photon. Alternatively, it can undergo in a proton transfer reaction (ESIPT) to structure $D$ at $S_{1}{ }_{1}$, decreasing its energy level. The emission from $D$ by a long wavelength photon leads to the instable structure $E$, which finally returns to the starting point (A) without a transition state (TS). The mechanism at state $D$ can branch toward state $F$, which provide a longer wavelength photon, resulting a local minimum structure $G$. The energy values (red numbers, given in $\mathrm{kJ} \mathrm{mol}^{-1}$ ) were calculated at M06-2X/6-31+ $+\mathrm{G}(\mathrm{d}, \mathrm{p}) / / \mathrm{PCM}(\mathrm{MeOH})$ level of theory. ESIPT: Excited-state intramolecular proton transfer; GSIPT: Ground-state intramolecular proton transfer.

however, they prove the relevant participation of the phenylamino moiety in the global charge distribution as an electron donating charge-transfer group. The electron donation of the phenylamino moiety increases during the excited state proton transfer as illustrated by the resonance structures in Figure 8 , and the dipole moment changes from 14.96 (C) to 11.32 Debye (D).

The analysis of the fluorescent mechanism in $1 \mathrm{c}$ revealed no significant deviation from that of $\mathrm{o}$-HOBDI described elsewhere. ${ }^{[59]}$ One minor difference is in the larger number of protonated and deprotonated forms that the molecules of $1 \mathrm{c}$ assume at various $\mathrm{pH}$. Therefore, it was concluded that the incorporation of the phenylamino moiety allowed the improvement in the quantum yield without compromising the ESIPT mechanism.

Consequently, in the second development step, we systematically varied the substituent at position 4 by introducing various electron donating amino groups $(\mathbf{1} \mathbf{e}-\mathbf{1} \mathbf{k})$ and the electron withdrawing nitro group $(1 \mathrm{I})$, while keeping the $2-\mathrm{OH}$ substituent in place to realise further improvements (Figure 1). The UV-Vis spectra of these compounds display red-shifted electronic transitions with peaks between 417 and $468 \mathrm{~nm}$ (Table 1, Table S1 and Figure S1). In contrast with that of $1 \mathrm{c}$, the emission spectra of $1 \mathrm{e}-1 \mathrm{l}$ exhibit one regularly shaped band with maxima in the range of $507-553 \mathrm{~nm}$. Even the simplest dialkylamino modification at this position, such as the introduction of a dimethylamino group (1 e), produces a large increase in the brightness relative to that of $1 \mathrm{c}$. However, the Stokes shift of $1 \mathrm{e}$ is somewhat lower $(82 \mathrm{~nm}$ or $0.466 \mathrm{eV}$, Table 1, Figure 9) than the exceptionally high value observed in the case of $1 \mathrm{c}$. The presence of other, bulkier, and more complex substituents, like diethylamino (1 $\mathbf{f})$, azetidine $(\mathbf{1} \mathbf{g}), 2,2-$ difluoro azetidine $(\mathbf{1} \mathbf{h})$, julolidine $(\mathbf{1} \mathbf{i})$, tetramethyl julolidine $(\mathbf{1} \mathbf{j})$, and ethyl-trimethyl-quinoline $(\mathbf{1} \mathrm{k})$, retains the Stokes shift in a similar range $\left(\Delta \lambda_{\max }=70-90 \mathrm{~nm}\right)$. Fluorescence emission intensities vary more significantly among the 4-diakylamino substituted compounds. Nevertheless, all of them display much stronger fluorescence than the mono-hydroxy substituted molecules (Table 1, Figure 9). The QYs of the bulkier dialkylamine derivatives ( $\mathbf{1} \mathbf{f}, \mathbf{1} \mathbf{i}-\mathbf{1} \mathbf{k}$ ) are roughly twice as high as those of the dimethylamine and azetidine derivatives (1 e, $\mathbf{1}$ g-1 h). This trend could be attributed to the formation of non-radiative twisted internal charge transfer (TICT) species in excited state in the latter group. ${ }^{[60]}$ The julolidine derivatives $(\mathbf{1} \mathbf{i}, \mathbf{1} \mathbf{j})$ show the largest emission intensity enhancement by a factor of 42.5 relative to the emission of $1 \mathrm{a}$. The contribution of the phenylamino moiety to the attractive photophysical properties should be highlighted once again. ${ }^{[31]}$ The QY increased 3.5 times (1 i) and 5.2 times (1 $\mathbf{f}$ ) compared to previously synthetised methylimidazolone derivatives. ${ }^{[44]}$ Interestingly, the introduction of a 


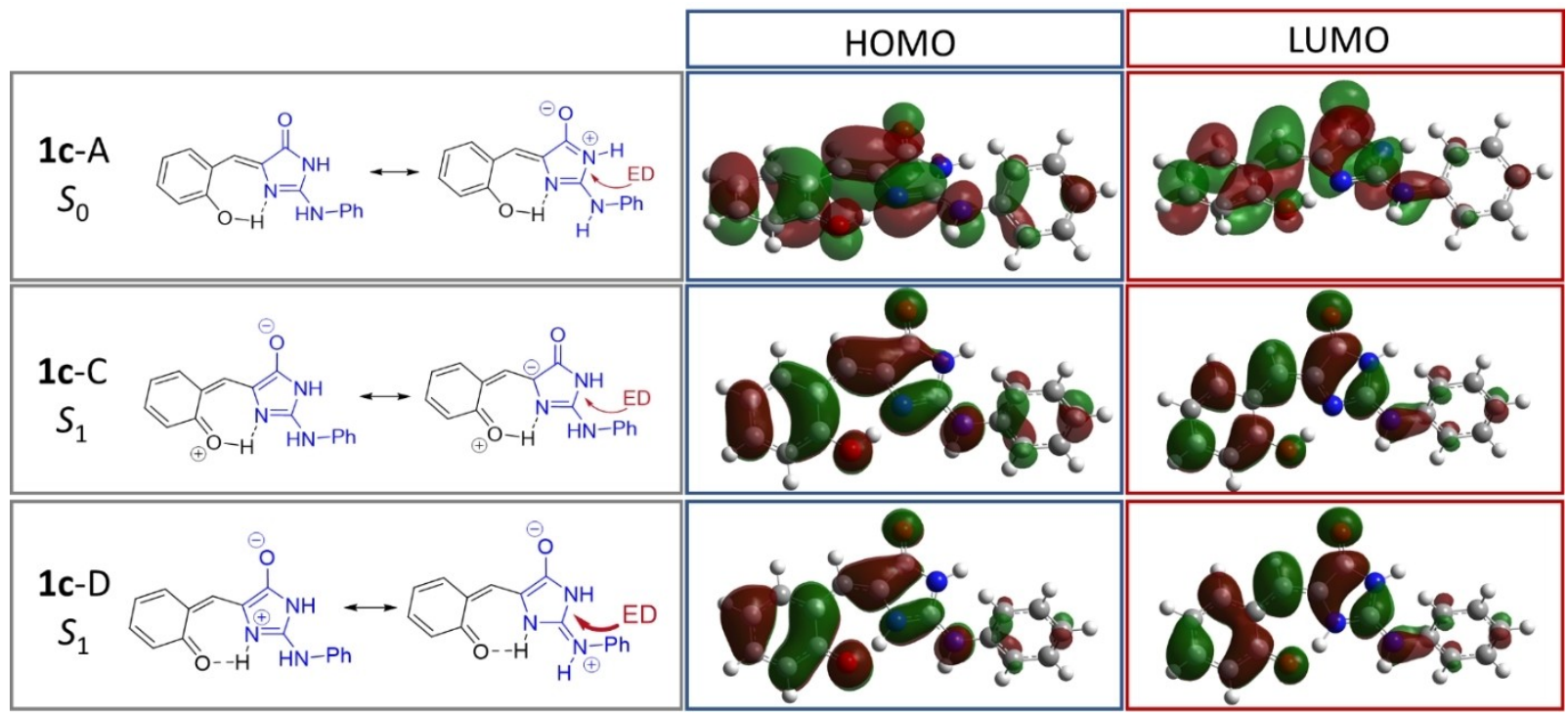

Figure 8. The optimised relevant resonance structures (left) indicating electron donation (ED) effect from the phenylamino group, and the corresponding the HOMO (middle) and the LUMO (right) representation for the ground state (A), the first S1 excited-state minimum (C) and the S1 excited state after the ESIPT (D) for $1 \mathrm{c}$ at the M06-2X/6-31+ $+\mathrm{G}(\mathrm{d}, \mathrm{p}) / / \mathrm{PCM}(\mathrm{MeOH})$ level of theory.

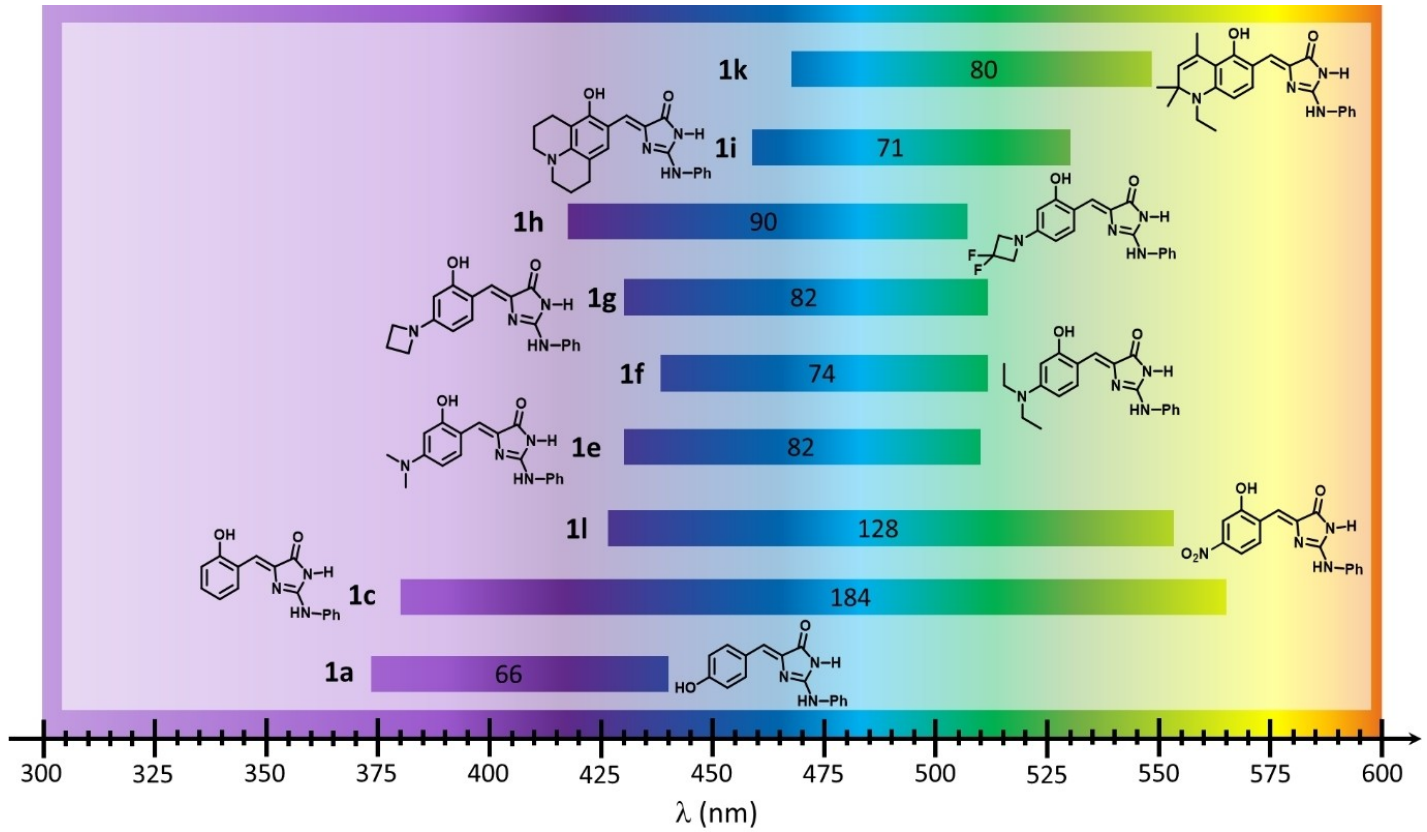

Figure 9. Illustrative summary of the spectrophysical properties of the prepared compounds 1 in methanol. Lengths of the horizontal-coloured lines correspond the values of the observed Stokes shift.

nitro group at position 4 (1 I) quenches the fluorescent intensity, albeit the Stokes shift is notably high at over $120 \mathrm{~nm}$.

We also examined the substituent effects of the $\mathrm{NO}_{2}(1 \mathrm{l})$ and $\mathrm{NMe}_{2}$ (1 e) groups on the fluorescence mechanism compared to the unsubstituted $1 \mathrm{c}$ using computational chemistry. The $C$ and $D$ excited state tautomers of the unsubstituted (1 c) and the nitro derivatives (1 I) are represented as stationary points on the excited state potential energy surface with energy differences of $+9.5 \mathrm{~kJ} \mathrm{~mol}^{-1}$ and
$+11.0 \mathrm{~kJ} \mathrm{~mol}^{-1}$, respectively. The excess of excitation energy (ca $30 \mathrm{~kJ} \mathrm{~mol}^{-1}, \mathrm{~B} \rightarrow \mathrm{C}$ step) in these cases is higher than the estimated barrier of the $C \rightarrow D$ transformation - also facilitated by proton tunnelling effect. The state $F$ is also an existing stationary point for $1 \mathrm{c}$ and $1 \mathrm{l}$ at a higher energy level. Importantly, the relative energy of $\mathrm{F}$ is too high $\left(+38.1 \mathrm{~kJ} \mathrm{~mol}^{-1}\right)$ in the case of $1 \mathrm{I}$ to be involved in the process, in contrast with $1 \mathrm{c}-\mathrm{F}$. Consequently, in the case of $1 \mathrm{l}$, emission occurs from state $D$, rather than state $F$. The analogous geometry optimisa- 
tions for the amino derivative (1 e) resulted in stationary point for state $C$, while its D tautomer did not correspond to a minimum on the potential energy surface, ergo proved to be unstable. While state $1 \mathrm{e}-\mathrm{F}$ is in an energy minimum, its energy level is significantly higher $\left(+45.6 \mathrm{~kJ} \mathrm{~mol}^{-1}\right)$ than the excess of excitation energy $\left(30 \mathrm{~kJ} \mathrm{~mol}^{-1}\right)$, hence it is unreachable during the excitation state transformations (Figure 10). These calculations were in good agreement with our experimental findings namely, that $1 \mathrm{c}$ and $1 \mathrm{I}$ display larger Stokes shifts $(184 \mathrm{~nm}$; $128 \mathrm{~nm}$ respectively), while 1 e has a moderate shift of $82 \mathrm{~nm}$ (Figure 9).

These results suggest that the moderate Stokes shifts of the 4-dialkylamino derivatives (1 e-1 I) can be attributed to the absence of ESIPT mechanism. As the ICT mechanism is less sensitive to the solvent medium than ESIPT, lower solvatochromism is expected for $\mathbf{1} \mathbf{e - 1} \mathbf{l}$, where the latter mechanism is absent, than in the case of $1 \mathrm{c}$. This notion is supported by the screening of solvent medium performed with $1 \mathrm{f}$ (Figure $\mathrm{S} 2$ and

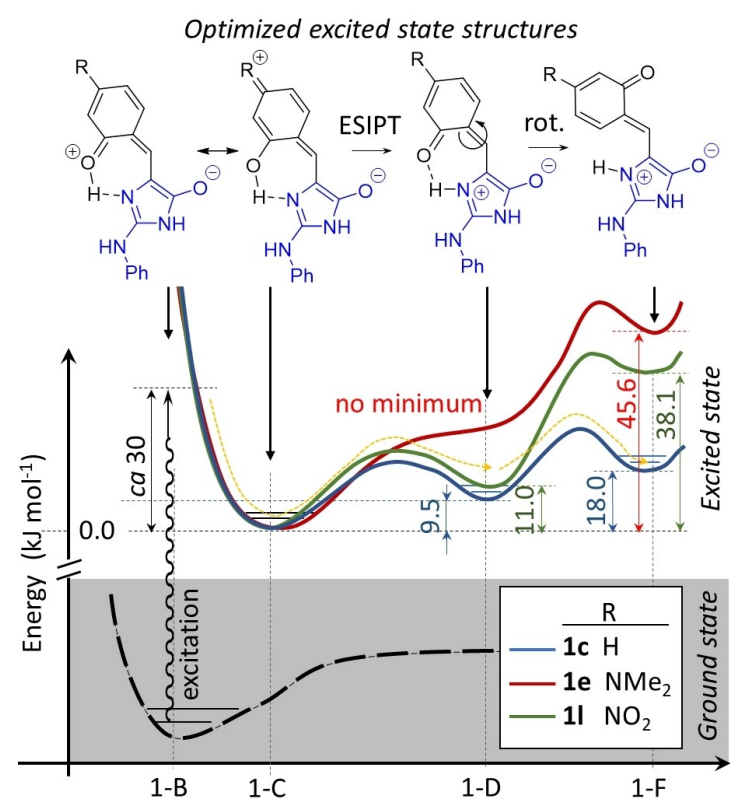

Figure 10. Calculated potential energy minima of the excited state structures of $1 \mathrm{c}, 1 \mathrm{e}$ and $1 \mathrm{I}$. Dotted yellow arrow illustrates the direction of the relaxation process. The energy values were calculated at M06-2X/6-31+ $+\mathrm{G}(\mathrm{d}, \mathrm{p})$ level of theory.

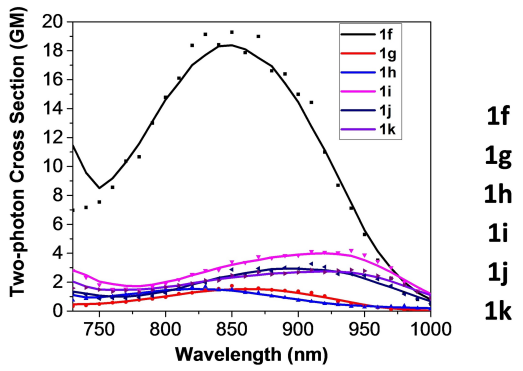

$\begin{array}{cc}\lambda\left(\text { TPCS }_{\max }\right) & \text { TPCS (GM) } \\ (\mathrm{nm}) & \\ 850 & 18.4 \\ 865 & 1.8 \\ 820 & 1.8 \\ 920 & 4.1 \\ 890 & 3.0 \\ 925 & 2.8\end{array}$

Figure 11. Two-photon cross sections (TPCS) of compounds $\mathbf{1} \mathbf{f}-\mathbf{k}$ DMSO (left) and the maximum TPCS values for $\mathbf{1} \mathbf{f}-\mathbf{k}$ in DMSO (right). $\lambda\left(\right.$ TPCS $\left._{\max }\right)$ is the wavelength where the TPCS is maximal. GM: Goeppert-Mayer unit.
Figure S3). Previous reports described similar observations regarding the absence of ESIPT for dialkylamino derivatives of o-HOBDI. ${ }^{[44]}$ Therefore, it can be concluded that the presence of the phenylamino moiety does not alter significantly the ESIPT capability of GFP analogue chromophores.

The compounds with the best one-photon QYs ( $\mathbf{1} \mathbf{f}-\mathbf{k})$ were also investigated in a two-photon excitation study in both DMSO (Figure 11) and EtOH (Figure S4) solvents. Their twophoton cross section (TPCS) values were determined to assess their application potential in the field of two-photon imaging microscopy. The excitation range spanned from 700 to $1000 \mathrm{~nm}$ and the emitted light was collected between 475-575 $\mathrm{nm}$.

In DMSO, $1 \mathrm{f}$ was found to exhibit the highest $\mathrm{TPCS}_{\max }$ value (18.4 Goeppert-Mayer unit, GM), roughly a magnitude higher than any other studied compound. The observed TPCS values of 1.8-18.4 GM are comparable to the values typical of the fluorescein family. ${ }^{[61]}$ It should be noted that the studied compounds (1 $\mathbf{f}-\mathbf{k}$ ) were primarily optimised for one-photon fluorescence, thus their structures do not have the features conventional high-TPCS dyes. ${ }^{[62]}$ Nevertheless, these derivatives are already more promising for two-photon imaging microscopy applications than $p$-HOBDI, that has practically no twophoton cross section. ${ }^{[63]}$

In the case of $\mathbf{1} \mathbf{g}, \mathbf{1} \mathbf{f}$ and $\mathbf{1} \mathbf{j}$ the peak of two-photon fluorescence can be found at slightly lower excitation wavelengths than the double of the one-photon excitation maximum (Figure 12). This phenomenon indicates that that higher excited singlet states are reached with greater probability via two-photon excitation. Two-photon excitation experiments in DMSO (Figure 11) and EtOH (Figure S4) revealed that TPCS values and their wavelength positions are highly solvent dependent, which is the result of vibronic couplings of excited states with the solvent environment. Among the studied compounds, the TPCS ${ }_{\max }$ wavelength of $\mathbf{1} \mathbf{f}$ has the smallest solvent dependence $(\sim 5 \mathrm{~nm})$. The observation that TPCS values are higher in less polar solvents is in line with literature findings for other dyes, e.g. rhodamine, ${ }^{[64]}$ and is also indicative of vibronic couplings with the solvent.

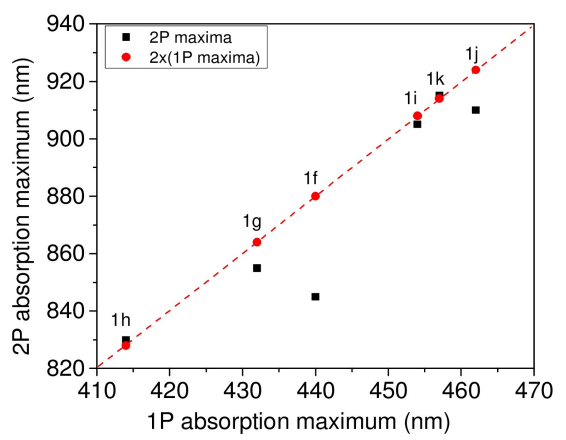

Figure 12. Correlation between the one-photon (1P) and two-photon (2P) excitation wavelengths for $\mathbf{1} \mathbf{f}-\mathbf{k}$. Coinciding data points for certain compounds indicate cases when $2 \mathrm{P}$ transition occurs between the same energy levels as the $1 \mathrm{P}$ absorption. 


\section{Conclusion}

In this work, several new GFP analogue fluorophores containing a 2-(phenylamino)imidazolone scaffold were synthesised, and their UV/Vis absorption and fluorescence spectroscopic properties were determined. The investigation revealed that the introduction of the hydroxyl group into position 2 of the benzylidene moiety not only enhanced the emission intensity, but also dramatically increased the Stokes shift (up to $185 \mathrm{~nm}$ ). The ESIPT mechanism in the fluorescence of $1 \mathrm{c}$ was proved by quantum chemical calculations and spectroscopic studies. Solvent effect studies (MeOH, DCM, THF, MeCN, DMSO, and HEPES buffer) on spectroscopic features of the fluorophores revealed significant solvation and $\mathrm{pH}$ dependence. Compounds $\mathbf{1} \mathbf{f}-\mathbf{k}$ (dialkylamino group in position 4 of benzylidene moiety) showed potential for spectroscopic applications due to their high brightness and distinct absorption and emission bands. These features enable selective excitation and detection in biological imaging applications. Moreover, enhanced twophoton cross section was observed for compounds $\mathbf{1} \mathbf{f}-\mathbf{k}$, which is relevant for certain neurobiological applications. In conclusion, incorporation of specific beneficial functional groups in the key positions of the fluorophore molecules proved to be a feasible strategy to improve the spectroscopic properties (QY, Stokes shift and two-photon cross section). Furthermore, the thorough understanding of the roles these groups play in the fluorescence will facilitate the further development of fluorescent dyes for various spectroscopic and imaging applications.

\section{Experimental Section}

Reagents and solvents were purchased from Sigma Aldrich in reagent grade and used as received. NMR solvents were purchased from Eurisotop. 2-Anilino-1,5-dihydroimidazole-4-one was synthetized according to the literature procedure. ${ }^{[31]}$

${ }^{1} \mathrm{H}$ NMR and ${ }^{13} \mathrm{C}\left\{{ }^{1} \mathrm{H}\right\}$ NMR were recorded at $600 / 500 \mathrm{MHz}$, $151 / 126 \mathrm{MHz}$ on Bruker Avance 500 or 300 spectrometers. All chemical shifts are quoted in parts per million (ppm), measured from the centre of the signal except in the case of multiplets, which are quoted as a range. ${ }^{1} \mathrm{H}$ NMR and ${ }^{13} \mathrm{C}$ chemical shifts are referenced to the residual solvent peak of $\left(\mathrm{CD}_{3}\right)_{2} \mathrm{SO}\left({ }^{1} \mathrm{H}\right.$ referenced to $2.50 \mathrm{ppm}$ and ${ }^{13} \mathrm{C}$ referenced to $39.52 \mathrm{ppm}$ ). Coupling constants are given with an accuracy of $0.1 \mathrm{~Hz}$. Splitting patterns are abbreviated as follows: singlet (s), doublet (d), triplet (t), quartet (q), quintet (quint), multiplet (m), broad singlet (brs), broad doublet (brd) and combinations thereof. Assignment of spectra was aided by DEPT 135 and 1D (NOESY), 2D NMR spectroscopy (COSY, HSQC and $H M B C$ ). The NMR assignations accompany the spectra in the Supplementary Information.

HRMS data were obtained using either electrospray (ESI) or electron impact (EI) ionization techniques, using an Agilent 6230 (equipped with an ion-trap) and a Waters Autospec (equipped with a magnetic sector) instruments, respectively. Data processing was executed within the Excalibur and MassLynx software.

Gradient elution preparative HPLC was applied (HPLC Gilson 333 instrument, UV detector $220 \mathrm{~nm}$ ) on a Phenomenex Gemini C18, $250 \times 50.00 \mathrm{~mm} ; 10 \mu \mathrm{m}, 110 \mathrm{~A}$ column using $0.4 \mathrm{~g} \mathrm{NH}_{4} \mathrm{HCO}_{3}$ in $1 \mathrm{~L}$ water and acetonitrile $(A / B)$ or $10 \mathrm{~mL}$ trifluoroacetic acid in $1 \mathrm{~L}$ water and acetonitrile $(C / B)$ as the two solvents.
UV-Vis absorption spectra in the wavelength range of $220-700 \mathrm{~nm}$ were recorded on a Thermo Scientific Evolution 220 spectrometer in a quartz cuvette (pathlength $=1.0 \mathrm{~cm}$ ) equipped with a PTFE stopper. The general sample preparation protocol involved the dissolution of $1-3 \mathrm{mg}$ of the studied compounds in $50.0 \mathrm{~mL}$ methanol (or in other solvents) and then a dilution to the suitable concentrations $\left(1.0-8.8 \times 10^{-5} \mathrm{M}\right)$ based on the UV-Vis absorption properties of the compounds. The spectrum of the pure solvent was subtracted from the sample spectra. Using the corrected spectra, the molar absorbance $(\varepsilon)$ at a specific wavelength value was calculated, and the position of a selected absorption band $\left(\lambda_{\max }\right)$ and the full molar absorption spectra of the compounds were determined.

Fluorescence emission data were measured on a Hitachi F-4500 spectrophotometer in a quartz cell with $1.0 \mathrm{~cm}$ pathlength. Slit widths were selected to provide $5 \mathrm{~nm}$ and $10 \mathrm{~nm}$ bandpass for the excitation and emission beams, respectively. Emission data were normalised to the intensity of a probe body, as an external reference, recorded every day. Solvent background spectra (emission spectra or excitation scans) were subtracted from the spectra of samples. Sample solutions were prepared by dilutions from the stock solutions used for the recording of the UV/Vis absorption spectra. The final concentration of the solutions prepared for fluorescence experiments was around $5 \mu \mathrm{M}$. The compounds were excited at their absorption maxima $\left(\lambda_{\max }\right)$ determined during UV/Vis absorption measurements. QYs were calculated by ratiometric method. ${ }^{[58]}$

The two-photon absorption cross sections (TPCSs) were determined with the two-photon excited fluorescence (TPEF) method. ${ }^{[65]}$ The measurements were performed using an inverted two-photon microscope (FemtoSmart2D, Femtonics), equipped with a XLUMPFLN20XW Olympus objective (numerical aperture; $N A=1.0$ ) and a tuneable high-power Ti:Sapphire laser (Coherent Chameleon Discovery COM5, wavelength of the excitation light is between $700 \mathrm{~nm}$ and $1040 \mathrm{~nm}$ ). The incident light source was focused into at capillary filled with either the sample or the reference solution (Rhodamine 6G in $\mathrm{MeOH}^{[66]}$ ) and integrated fluorescence emission was detected in a wavelength window from 475 to $575 \mathrm{~nm}$ (green channel of the microscope). The power of the laser source was kept constant at $15 \mathrm{~mW}$. TPCS at each excitation wavelength was calculated according to the following Equation (1):

$$
T P C S_{\mathrm{s}}=\operatorname{TPCS}_{\mathrm{ref}} \cdot \frac{A_{\mathrm{sam}} \cdot c_{\mathrm{ref}} \cdot a_{\mathrm{ref}} \cdot n_{\mathrm{D}, \mathrm{ref}}}{A_{\mathrm{ref}} \cdot c_{\mathrm{sam}} \cdot a_{\mathrm{sam}} \cdot n_{\mathrm{D}, \mathrm{sam}}}
$$

where $A$ is the mean TPEF emission intensity, $c$ is the dye concentration, $n_{\mathrm{D}}$ is the refractive index of the solvent measured at the sodium D-line; $a$ is a variable derived from one-photon emission measurements calculated as the integral of one-photon emission spectrum from 475 to $575 \mathrm{~nm}$ divided by the total one-photon emission spectrum integral. Lower indices ref and $s$ refer to the reference compound and the sample, respectively.

For theoretical calculations Gaussian 16 program package $(\mathrm{G} 16){ }^{[67]}$ using convergence criteria of $3.0 \times 10^{-4}, 4.5 \times 10^{-4}, 1.2 \times 10^{-3}$ and $1.8 \times 10^{-3}$, for the gradients of the root mean square (RMS) force, maximum force, RMS displacement, and maximum displacement vectors, were used, respectively. Computation was carried out at M06-2X/6-31 + $+G(d, p)$ level of theory, using integral equation formalism-polarisable continuum model (IEFPCM) method with the parameters of methanol. ${ }^{[68]}$ The method and basis sets were chosen for their reliability shown in earlier studies. ${ }^{[69-71]}$ The vibrational frequencies were computed at the same levels of theory, as used for geometry optimisation, in order to properly confirm that all structures reside at minima on their potential energy hypersurfaces 
(PESs). Thermodynamic functions, such as energy $(U)$, enthalpy $(H)$, Gibbs free energy $(G)$, and entropy $(S)$ were computed for $298.15 \mathrm{~K}$, using the quantum chemical, rather than the conventional thermodynamic reference state.

\section{General procedure for the synthesis of 5-arylmethylene-2-(phenylamino)-imidazolone derivatives}

The solution of 2-(phenylamino)-1,5-dihydroimidazole-4-one ( 1 equiv.), benzaldehyde derivative (1 equiv.) and a catalytic amount of pyrrolidine ( $3 \mathrm{Vol} \%$ ) in acetic acid $\left(3.33 \mathrm{~mL} \mathrm{mmol}^{-1}\right.$ relative to the substrate) was stirred at $110^{\circ} \mathrm{C}$ under nitrogen atmosphere. The crude mixture was evaporated, diluted with $\mathrm{EtOH}$ and solids were filtered. If the HPLC purity was lower than $95 \%$, the crude products were recrystallised from small amount of EtOH then filtered off. In the cases of $\mathbf{1} \mathbf{a}-\mathbf{f}, \mathbf{i}, \mathbf{I}$, the crude product was purified by preparative HPLC.

\section{5-(4-Hydroxybenzylidene)-2-(phenylamino)-3,5-dihydro-4H-imi-} dazol-4-one ( $1 \mathrm{a}$ ): Yield: $78 \%$; yellow solid; $\mathrm{mp}:>250^{\circ} \mathrm{C}$ (decomp.). The spectroscopical properties were in agreement with the literature. ${ }^{[31]}$

5-(3-Hydroxybenzylidene)-2-(phenylamino)-3,5-dihydro-4H-imidazol-4-one (1 b): Yield: $69 \%$; yellow solid; $\mathrm{mp}:>240^{\circ} \mathrm{C}$ (decomp.). ${ }^{1} \mathrm{H}$ NMR $\left(500 \mathrm{MHz}, \mathrm{DMSO}-\mathrm{d}_{6}\right) \delta$ (ppm) 10.64 (brs, $\left.1 \mathrm{H}, \mathrm{OH} / \mathrm{NH}\right), 9.80$ (brs, 1H, OH/NH), $9.44(\mathrm{~s}, 1 \mathrm{H}, \mathrm{OH} / \mathrm{NH}), 7.82(\mathrm{~d}, J=8.0 \mathrm{~Hz}, 2 \mathrm{H}, \mathrm{C}[3]-$ $\mathrm{H}), 7.54(\mathrm{~s}, 1 \mathrm{H}, \mathrm{C}[10]-\mathrm{H}), 7.49(\mathrm{~d}, J=7.7 \mathrm{~Hz}, 1 \mathrm{H}, \mathrm{C}[14]-\mathrm{H}), 7.43-7.33$ $(\mathrm{m}, 2 \mathrm{H}, \mathrm{C}[2]-\mathrm{H}), 7.21(\mathrm{t}, J=7.9 \mathrm{~Hz}, 1 \mathrm{H}, \mathrm{C}[1]-\mathrm{H}), 7.08(\mathrm{t}, J=7.4 \mathrm{~Hz}, 1 \mathrm{H}$, $\mathrm{C}[13]-\mathrm{H}), 6.73(\mathrm{dd}, J=8.0,2.4 \mathrm{~Hz}, 1 \mathrm{H}, \mathrm{C}[12]-\mathrm{H}), 6.42(\mathrm{~s}, 1 \mathrm{H}, \mathrm{C}[8]-\mathrm{H})$; ${ }^{13} \mathrm{C}$ NMR $\left(126 \mathrm{MHz}\right.$, DMSO-d $\left.\mathrm{d}_{6}\right) \delta$ (ppm) 170.4, 157.2, 154.9, 140.5, 138.8, 136.5, 129.3, 129.0, 122.8, 121.6, 119.4, 116.8, 115.4, 115.0; HR-MS:(ESI) calcd. for $\mathrm{C}_{16} \mathrm{H}_{14} \mathrm{~N}_{3} \mathrm{O}_{2} \quad 280.1081 \quad[\mathrm{M}+\mathrm{H}]^{+}$, found 280.1080, Df. $=-0.19 \mathrm{ppm}$.

5-(2-Hydroxybenzylidene)-2-(phenylamino)-3,5-dihydro-4H-imidazol-4-one (1 c): Yield: $71 \%$; yellow solid; $\mathrm{mp}:>250^{\circ} \mathrm{C}$ (decomp.); ${ }^{1} \mathrm{H}$ NMR $\left(500 \mathrm{MHz}, \mathrm{DMSO}-\mathrm{d}_{6}\right.$ ) $\delta$ (ppm) 11.66 (brs, 1H, OH/NH), 10.94 (brs, $1 \mathrm{H}, \mathrm{OH} / \mathrm{NH}), 9.96$ (brs, $1 \mathrm{H}, \mathrm{OH} / \mathrm{NH}), 7.94$ (brd, $J=6.5 \mathrm{~Hz}, 1 \mathrm{H}$, $\mathrm{C}[14]-\mathrm{H}), 7.61(\mathrm{~d}, J=7.8 \mathrm{~Hz}, 2 \mathrm{H}, \mathrm{C}[3]-\mathrm{H}), 7.39(\mathrm{t}, J=7.8 \mathrm{~Hz}, 2 \mathrm{H}, \mathrm{C}[2]-$ $\mathrm{H}), 7.19-7.13(\mathrm{~m}, 1 \mathrm{H}, \mathrm{C}[12]-\mathrm{H}), 7.11(\mathrm{t}, J=7.8 \mathrm{~Hz}, 1 \mathrm{H}, \mathrm{C}[1]-\mathrm{H}), 6.86-$ $6.80(\mathrm{~m}, 2 \mathrm{H}, \mathrm{C}[11]-\mathrm{H}, \mathrm{C}[13]-\mathrm{H}), 6.72(\mathrm{~s}, 1 \mathrm{H}, \mathrm{C}[8]-\mathrm{H}) ;{ }^{13} \mathrm{C}$ NMR $\left(126 \mathrm{MHz}, \mathrm{DMSO}-\mathrm{d}_{6}\right) \delta$ (ppm) 169.2, 156.6, 153.0, 138.2, 137.3, 132.7, $130.5,129.1,123.5,121.5,120.2,119.3,116.9,113.1$; HR-MS:(ESI) calcd. for $\mathrm{C}_{16} \mathrm{H}_{13} \mathrm{~N}_{3} \mathrm{O}_{2} 280.1086[\mathrm{M}+\mathrm{H}]^{+}$, found 280.1092, Df. $=$ $2.14 \mathrm{ppm}$.

5-(2-Methoxybenzylidene)-2-(phenylamino)-3,5-dihydro-4H-imidazol-4-one (1 d): Yield: $78 \%$; beige solid; $\mathrm{mp}:>250^{\circ} \mathrm{C}$ (decomp.); ${ }^{1} \mathrm{H}$ NMR (500 MHz, DMSO-d ) $^{\circ} \delta$ (ppm) 10.66 (brs, 1H, NH), 9.83 (brs, $1 \mathrm{H}, \mathrm{NH}), 8.70(\mathrm{~d}, J=7.7 \mathrm{~Hz}, 1 \mathrm{H}, \mathrm{C}[3]-\mathrm{H}), 7.79(\mathrm{~d}, J=7.9 \mathrm{~Hz}, 2 \mathrm{H}, \mathrm{C}[14]-$ $\mathrm{H}), 7.38(\mathrm{t}, J=7.7 \mathrm{~Hz}, 2 \mathrm{H}, \mathrm{C}[2]-\mathrm{H}), 7.29(\mathrm{t}, J=7.9 \mathrm{~Hz}, 1 \mathrm{H}, \mathrm{C}[12]-\mathrm{H})$, $7.07(\mathrm{t}, J=7.5 \mathrm{~Hz}, 1 \mathrm{H}, \mathrm{C}[1]-\mathrm{H}), 7.03(\mathrm{t}, J=7.1 \mathrm{~Hz}, 1 \mathrm{H}, \mathrm{C}[13]-\mathrm{H}), 7.03$ (d, J=7.8 Hz, 1H, C[11]-H), $6.91(\mathrm{~s}, 1 \mathrm{H}, \mathrm{C}[8]-\mathrm{H}), 3.86\left(\mathrm{~s}, 3 \mathrm{H}, \mathrm{C}[15]-\mathrm{H}_{3}\right)$; ${ }^{13} \mathrm{C}$ NMR $(126 \mathrm{MHz}$, DMSO-d 6 ) $\delta$ (ppm) 170.4, 157.3, 154.9, 140.0, $138.8,130.4,129.5,128.9,123.7,122.8,120.5,119.4,110.9,107.7$, 55.6; HR-MS:(ESI) calcd. for $\mathrm{C}_{17} \mathrm{H}_{15} \mathrm{O}_{2} \mathrm{~N}_{3} \mathrm{Na} 316.1056[\mathrm{M}+\mathrm{Na}]^{+}$, found 316.1043 Da, Df. $=-4.26 \mathrm{ppm}$.

5-(2-Hydroxy-4-dimethylaminobenzylidene)-2-(phenylamino)-3,5dihydro-4H-imidazol-4-one (1 e): Yield: $68 \%$; orange solid; $\mathrm{mp}$ : $>250{ }^{\circ} \mathrm{C}$ (decomp.); ${ }^{1} \mathrm{H}$ NMR $\left(500 \mathrm{MHz}, \mathrm{DMSO}^{\left.-\mathrm{d}_{6}\right)} \delta\right.$ (ppm) 12.47 (brs, 1H, NH/OH), 10.76 (brs, 1H, NH/OH), 9.76 (brs, 1H, NH/OH), 7.51 (brd, 2H, C[2]-H), 7.50-7.43 (m, 1H, C[14]-H), $7.37(\mathrm{t}, J=7.8 \mathrm{~Hz}, 2 \mathrm{H}$, $\mathrm{C}[2]-\mathrm{H}), 7.08(\mathrm{t}, J=7.8 \mathrm{~Hz}, 1 \mathrm{H}, \mathrm{C}[1]-\mathrm{H}), 6.60(\mathrm{~s}, 1 \mathrm{H}, \mathrm{C}[8]-\mathrm{H}), 6.26(\mathrm{dd}$, $J=9.0,2.5 \mathrm{~Hz}, 1 \mathrm{H}, \mathrm{C}[13]-\mathrm{H}), 6.08(\mathrm{~d}, J=2.5,1 \mathrm{H}, \mathrm{C}[11]-\mathrm{H}), 2.93(\mathrm{~s}, 6 \mathrm{H}$, $\left.\mathrm{C}[15]-\mathrm{H}_{3}\right) ;{ }^{13} \mathrm{C}$ NMR/DEPTQ (126 MHz, DMSO-d $\left.\mathrm{d}_{6}\right) \delta$ (ppm) 168.9, $158.8,153.3,150.5,138.8,135.5,129.5,129.1,123.5,120.2,117.8$,
110.3, 104.9, 99.9, 40.0; HR-MS:(ESI) calcd. for $\mathrm{C}_{18} \mathrm{H}_{18} \mathrm{~N}_{4} \mathrm{O}_{2} 322.1430$ $[\mathrm{M}+\mathrm{H}]^{+}$, found 323.1517, Df. $=-4.54 \mathrm{ppm}$.

5-(2-Hydroxy-4-diethylaminobenzylidene)-2-(phenylamino)-3,5dihydro-4H-imidazol-4-one (1f): Yield: $61 \%$; orange solid; $\mathrm{mp}$ : $>250^{\circ} \mathrm{C}$ (decomp.); ${ }^{1} \mathrm{H}$ NMR $(500 \mathrm{MHz}$, DMSO-d 6 ) $\delta$ (ppm) 12.52 (brs, 1H, NH/OH), 10.82 (brs, 1H, NH/OH), 9.80 (brs, 1H, NH/OH), 7.51 $(\mathrm{d}, J=8.0 \mathrm{~Hz}, 2 \mathrm{H}, \mathrm{C}[3]-\mathrm{H}), 7.46-7.40(\mathrm{~m}, 1 \mathrm{H}, \mathrm{C}[14]-\mathrm{H}), 7.37(\mathrm{t}, J=$ $7.7 \mathrm{~Hz}, 2 \mathrm{H}, \mathrm{C}[2]-\mathrm{H}), 7.07(\mathrm{t}, J=7.3 \mathrm{~Hz}, 1 \mathrm{H}, \mathrm{C}[1]-\mathrm{H}), 6.58(\mathrm{~s}, 1 \mathrm{H}, \mathrm{C}[8]-\mathrm{H})$, $6.20(\mathrm{dd}, J=8.8,2.5 \mathrm{~Hz}, 1 \mathrm{H}, \mathrm{C}[13]-\mathrm{H}), 6.04(\mathrm{~s}, 1 \mathrm{H}, \mathrm{C}[11]-\mathrm{H}), 3.33(\mathrm{q}$, $\left.J=7.0 \mathrm{~Hz}, 4 \mathrm{H}, \mathrm{C}[15]-\mathrm{H}_{2}\right), 1.09\left(\mathrm{t}, J=7.0 \mathrm{~Hz}, 6 \mathrm{H}, \mathrm{C}[16]-\mathrm{H}_{3}\right) .{ }^{13} \mathrm{C}$ NMR $\left(126 \mathrm{MHz}, \mathrm{DMSO}-\mathrm{d}_{6}\right) \delta$ (ppm) 168.3, 158.7, 150.3, 149.7, 138.4, 135.4, 131.3, 129.0, 123.0, 119.6, 117.7, 109.1, 103.9, 98.6, 43.8, 12.7; HRMS:(ESI) calcd. for $\mathrm{C}_{20} \mathrm{H}_{23} \mathrm{O}_{2} \mathrm{~N}_{4} 351.1816[\mathrm{M}+\mathrm{H}]^{+}$, found 351.1804, Df. $=-3.28 \mathrm{ppm}$.

5-(4-(Azetidin-1-yl)-2-hydroxybenzylidene)-2-(phenylamino)-3,5dihydro-4H-imidazol-4-one (1 g): DMF (2 mL) solution of 2-anilino1,5-dihydroimidazole-4-one $\quad(45 \mathrm{mg}, \quad 0.257 \mathrm{mmol}, \quad 1$ equiv.), $0.27 \mathrm{mmol}$ of 4-(azetidin-1-yl)-2-hydroxybenzaldehyde ${ }^{[55]}$ (1.05 equiv.) and $0.200 \mathrm{~mL}$ of pyrrolidine and $0.3 \mathrm{~mL}$ of acetic acid was stirred at $110^{\circ} \mathrm{C}$ for 1 hour. The crude reaction mixture was evaporated and purified by preparative HPLC. The fractions were collected and lyophilized. The compound $1 \mathbf{g}$ was isolated $(23.4 \mathrm{mg}$, Yield: $24 \%$ ) as an orange solid; $\mathrm{mp}:>150^{\circ} \mathrm{C}$ (decomp.). ${ }^{1} \mathrm{H}$ NMR $\left(600 \mathrm{MHz}, \mathrm{DMSO}-\mathrm{d}_{6}\right) \delta(\mathrm{ppm}) 11.75$ (brs, $\left.1 \mathrm{H}, \mathrm{NH} / \mathrm{OH}\right), 10.43$ (brs, $1 \mathrm{H}$, $\mathrm{NH} / \mathrm{OH}), 7.49(\mathrm{~d}, J=7.9 \mathrm{~Hz}, 2 \mathrm{H}, \mathrm{C}[3]-\mathrm{H}), 7.49-7.45(\mathrm{~m}, 1 \mathrm{H}, \mathrm{C}[14]-\mathrm{H})$, $7.41(\mathrm{t}, J=7.9 \mathrm{~Hz}, 2 \mathrm{H}, \mathrm{C}[2]-\mathrm{H}), 7.17(\mathrm{t}, J=7.3 \mathrm{~Hz}, 1 \mathrm{H}, \mathrm{C}[1]-\mathrm{H}), 6.71(\mathrm{~s}$, $1 \mathrm{H}, \mathrm{C}[8]-\mathrm{H}) 5.95(\mathrm{dd}, J=8.5 \mathrm{~Hz}, 2.3 \mathrm{~Hz}, 1 \mathrm{H}, \mathrm{C}[13]-\mathrm{H}), 5.82(\mathrm{~d}, J=$ $2.3 \mathrm{~Hz}, 1 \mathrm{H}, \mathrm{C}[11]-\mathrm{H}$ ), $3.87\left(\mathrm{t}, J=7.3 \mathrm{~Hz}, 4 \mathrm{H}, \mathrm{C}[15]-\mathrm{H}_{2}\right.$ ) 2.31 (quint, $J=$ $\left.7.3 \mathrm{~Hz}, 2 \mathrm{H}, \mathrm{C}[16]-\mathrm{H}_{2}\right) ;{ }^{13} \mathrm{C}$ NMR (151 MHz, DMSO-d $\left.\mathrm{d}_{6}\right) \delta$ (ppm) 167.3, $158.1,154.0,150.9,137.2,134.4,129.3,129.2,124.3,120.9,116.4$, 110.0, 103.3, 97.7, 51.3, 15.9. HR-MS:(ESI) calcd. for $\mathrm{C}_{19} \mathrm{H}_{19} \mathrm{O}_{2} \mathrm{~N}_{4}$ $335.1503[\mathrm{M}+\mathrm{H}]^{+}$, found 335.1492, Df. $=-3.3 \mathrm{ppm}$.

5-(4-(3,3-Difluoroazetidin-1-yl)-2-hydroxybenzylidene)-2-(phenylamino)-3,5-dihydro-4H-imidazol-4-one $(1 \mathrm{~h})$ : Yield: $38 \%$; yellow solid; $\mathrm{mp}:>175^{\circ} \mathrm{C}$ (decomp.). ${ }^{1} \mathrm{H}$ NMR $\left(500 \mathrm{MHz}, \mathrm{DMSO}_{6}\right) \delta 12.24$ (brs, NH/OH), 10.99 (brs, NH/OH), 10.04 (brs, NH/OH), 7.59 (brd, $J=$ $8.5 \mathrm{~Hz}, 1 \mathrm{H}, \mathrm{C}[14]-\mathrm{H}), 7.52(\mathrm{~d}, J=7.6 \mathrm{~Hz}, 2 \mathrm{H}, \mathrm{C}[3]-\mathrm{H}), 7.39(\mathrm{t}, J=8.0 \mathrm{~Hz}$, $2 \mathrm{H}, \mathrm{C}[2]-\mathrm{H}), 7.13(\mathrm{t}, J=7.4 \mathrm{~Hz}, 1 \mathrm{H}, \mathrm{C}[1]-\mathrm{H}), 6.66(\mathrm{~s}, 1 \mathrm{H}, \mathrm{C}[8]-\mathrm{H}), 6.09$ (dd, $J=8.5,2.4 \mathrm{~Hz}, 1 \mathrm{H}, \mathrm{C}[13]-\mathrm{H}), 5.98(\mathrm{~d}, J=2.3 \mathrm{~Hz}, 1 \mathrm{H}, \mathrm{C}[11]-\mathrm{H}), 4.31$ $\left(\mathrm{t}, J=12.2 \mathrm{~Hz}, 4 \mathrm{H}, \mathrm{C}[15]-\mathrm{H}_{2}\right) ;{ }^{13} \mathrm{C}$ NMR $\left(126 \mathrm{MHz}, \mathrm{DMSO}-\mathrm{d}_{6}\right) \delta$ (ppm) $168.1,157.9,151.9,151.4,137.7,134.3,129.0,129.0,123.6,120.2$, $116.45(\mathrm{t}, J=272.9 \mathrm{~Hz}), 115.6,112.1,104.5,100.0,62.44(\mathrm{t}, J=$ $25.6 \mathrm{~Hz}$ ). ${ }^{19} \mathrm{~F}$ NMR $\left(471 \mathrm{MHz}\right.$, DMSO-d $\left.\mathrm{d}_{6}\right) \delta-99.09$ (quint, $J=12.3 \mathrm{~Hz}$ ); HR-MS:(ESI) calcd. for $\mathrm{C}_{19} \mathrm{H}_{17} \mathrm{O}_{2} \mathrm{~N}_{4} \mathrm{~F}_{2} \quad 371.1314[\mathrm{M}+\mathrm{H}]^{+}$, found 371.1310, Df. $=-1.10 \mathrm{ppm}$.

5-((8-Hydroxyjulolidin-9-yl)methylene)-2-(phenylamino)-3,5-dihydro-4H-imidazol-4-one (1 i): Yield: $82 \%$; red solid; $\mathrm{mp}:>210^{\circ} \mathrm{C}$ (decomp.); ${ }^{1} \mathrm{H}$ NMR $\left(500 \mathrm{MHz}, \mathrm{DMSO}^{\left.-\mathrm{d}_{6}\right)} \delta\right.$ (ppm) 13.00 (brs, $1 \mathrm{H}, \mathrm{NH} /$ $\mathrm{OH}), 10.83$ (brs, $1 \mathrm{H}, \mathrm{NH} / \mathrm{OH}), 9.77$ (brs, $1 \mathrm{H}, \mathrm{NH} / \mathrm{OH}), 7.45$ (d, $J=$ $8.0 \mathrm{~Hz}, 2 \mathrm{H}, \mathrm{C}[3]-\mathrm{H}), 7.36(\mathrm{t}, J=7.8 \mathrm{~Hz}, 2 \mathrm{H}, \mathrm{C}[2]-\mathrm{H}), 7.08(\mathrm{t}, J=7.4 \mathrm{~Hz}$, $1 \mathrm{H}, \mathrm{C}[1]-\mathrm{H}), 6.77(\mathrm{~s}, 1 \mathrm{H}, \mathrm{C}[8]-\mathrm{H}), 6.44(\mathrm{~s}, 1 \mathrm{H}, \mathrm{C}[14]-\mathrm{H}), 3.16(\mathrm{t}, J=$ $\left.5,6 \mathrm{~Hz}, 2 \mathrm{H}, \mathrm{C}[17]-\mathrm{H}_{2} / \mathrm{C}[18]-\mathrm{H}_{2}\right), 3.13\left(\mathrm{t}, J=5.6 \mathrm{~Hz}, 2 \mathrm{H}, \mathrm{C}[17]-\mathrm{H}_{2} / \mathrm{C}[18]-\right.$ $\left.\mathrm{H}_{2}\right), 2.58\left(\mathrm{t}, J=6.8 \mathrm{~Hz}, 2 \mathrm{H}, \mathrm{C}[15]-\mathrm{H}_{2} / \mathrm{C}[20]-\mathrm{H}_{2}\right), 2.56(\mathrm{t}, J=6.8 \mathrm{~Hz}, 2 \mathrm{H}$, $\mathrm{C}[15]-\mathrm{H}_{2} / \mathrm{C}[20]-\mathrm{H}_{2}$ ), 1.83 (quint, $\left.J=6.1 \mathrm{~Hz}, 4 \mathrm{H}, \mathrm{C}[16]-\mathrm{H}_{2}, \mathrm{C}[19]-\mathrm{H}_{2}\right) ;{ }^{13} \mathrm{C}$ NMR $\left(126 \mathrm{MHz}\right.$, DMSO-d $\mathrm{d}_{6}$ ) $\delta$ (ppm) 167.9, 153.6, 148.8, 145.7, 138.1, 132.2, 130.1, 129.0, 123.1, 119.8, 119.7, 112.6, 108.8, 107.4, 49.4, 48.8, 26.5, 21.7, 21.1, 21.0; HR-MS:(ESI) calcd. for $\mathrm{C}_{22} \mathrm{H}_{22} \mathrm{O}_{2} \mathrm{~N}_{4} \mathrm{Na}$ 397.1635 $[\mathrm{M}+\mathrm{Na}]^{+}$, found: $397.1618, \mathrm{Df} .=-4.27 \mathrm{ppm}$.

5-((8-Hydroxy-1,1,7,7-tetramethyl-julolidin-9-yl)methylene)-2(phenylamino)-3,5-dihydro-4H-imidazol-4-one (1j): Yield: $23 \%$; dark red solid; mp: $>160{ }^{\circ} \mathrm{C}$ (decomp.); ${ }^{1} \mathrm{H}$ NMR $\left(500 \mathrm{MHz}, \mathrm{DMSO}-\mathrm{d}_{6}\right)$ $\delta$ (ppm) 12.88 (brs, 1H, NH), 10.72 (brs, 1H, NH), 9.74 (brs, 1H, NH), $7.54(\mathrm{~d}, J=7.9 \mathrm{~Hz}, 2 \mathrm{H}, 2 \times \mathrm{C}[3]-\mathrm{H}), 7.32(\mathrm{t}, J=7.9 \mathrm{~Hz}, 2 \mathrm{H}, 2 \times \mathrm{C}[2]-\mathrm{H})$, 
$7.10(\mathrm{~d}, J=7.3 \mathrm{~Hz}, 1 \mathrm{H}, \mathrm{C}[1]-\mathrm{H}), 7.08(\mathrm{~s}, 1 \mathrm{H}, \mathrm{C}[14]-\mathrm{H}), 6.55$ (s, 1H, C[8]$\mathrm{H}), 5.77(\mathrm{bs}, 1 \mathrm{H}, \mathrm{OH}), 3.16(\mathrm{t}, J=5.8 \mathrm{~Hz}, 2 \mathrm{H}, 2 \times \mathrm{C}[17]-\mathrm{H}), 3.12(\mathrm{t}, J=$ $5.5 \mathrm{~Hz}, 2 \mathrm{H}, 2 \times \mathrm{C}[18]-\mathrm{H}), 1.69(\mathrm{t}, J=5.5 \mathrm{~Hz}, 2 \mathrm{H}, 2 \times \mathrm{C}[19]-\mathrm{H}), 1.66(\mathrm{t}$, $J=5.8 \mathrm{~Hz}, 2 \mathrm{H}, 2 \times \mathrm{C}[16]-\mathrm{H}), 1.41(\mathrm{~s}, 6 \mathrm{H}, 6 \times \mathrm{C}[21,22]-\mathrm{H}), 1.21(\mathrm{~s}, 6 \mathrm{H}, 6 \times$ $\mathrm{C}[23,24]-H) .{ }^{13} \mathrm{C}$ NMR $\left(151 \mathrm{MHz}, \mathrm{DMSO}-\mathrm{d}_{6}\right) \delta$ (ppm) 167.4, 155.2, $148.7,145.2,138.1,130.3,129.9,128.8,128.6,122.9,122.3,120.0$, $119.5,115.9,110.5,46.5,46.0,36.3,32.1,31.2,30.9,29.4,28.5$. HRMS: (ESI) calcd. for $\mathrm{C}_{26} \mathrm{H}_{30} \mathrm{O}_{2} \mathrm{~N}_{4} \mathrm{Na} 453.2261[\mathrm{M}+\mathrm{Na}]^{+}$.

5-((1-Ethyl-7-hydroxy-2,2,4-trimethyl-1,2-dihydroquinolin-6-yl) methylene)-2-(phenylamino)-3,5-dihydro-4H-imidazol-4-one (1 k): Yield: $41 \%$; orange solid; $\mathrm{mp}:>195^{\circ} \mathrm{C}$ (decomp.). ${ }^{1} \mathrm{H}$ NMR $\left(500 \mathrm{MHz}, \mathrm{DMSO}-\mathrm{d}_{6}\right) \delta$ (ppm) 7.75-7.54 (m, 3H, C[3]-H, C[14]-H), $7.34(\mathrm{t}, J=7.8 \mathrm{~Hz}, 2 \mathrm{H}, \mathrm{C}[2]-\mathrm{H}), 7.13-7.02(\mathrm{~m}, 1 \mathrm{H}, \mathrm{C}[1]-\mathrm{H}), 6.75(\mathrm{~s}, 1 \mathrm{H}$, $\mathrm{C}[8]-\mathrm{H}), 5.99(\mathrm{~s}, 1 \mathrm{H}, \mathrm{C}[11]-\mathrm{H}), 5.19(\mathrm{~s}, 1 \mathrm{H}, \mathrm{C}[17]-\mathrm{H}), 3.31(\mathrm{q}, J=7.0 \mathrm{~Hz}$ $\left.2 \mathrm{H}, \mathrm{C}[20]-\mathrm{H}_{2}\right), 1.96\left(\mathrm{~s}, 3 \mathrm{H}, \mathrm{C}[16]-\mathrm{H}_{3}\right), 1.29\left(\mathrm{~s}, 6 \mathrm{H}, \mathrm{C}[19]-\mathrm{H}_{3}\right), 1.13(\mathrm{t}, J=$ $\left.6.8 \mathrm{~Hz}, 3 \mathrm{H}, \mathrm{C}[21]-\mathrm{H}_{3}\right) ;{ }^{13} \mathrm{C}$ NMR $\left(126 \mathrm{MHz}, \mathrm{DMSO}-\mathrm{d}_{6}\right) \delta(\mathrm{ppm}) 158.6$, $150.7,146.3,138.4,128.9,127.7,126.7,126.1,123.0,119.5,114.7$, 108.6, 97.1， 57.3，37.8， 28.9， 18.4, 13.9; HR-MS:(ESI) calcd. for $\mathrm{C}_{24} \mathrm{H}_{26} \mathrm{O}_{2} \mathrm{~N}_{4} \mathrm{Na} 425.1948[\mathrm{M}+\mathrm{Na}]^{+}$, found: 425.1959, Df. $=2.59 \mathrm{ppm}$.

4-(2-Hydroxy-4-nitrobenzylidene)-2-(phenylamino)-1H-imidazol5(4H)-one (1 l): Yield: $69 \%$; orange solid; $\mathrm{mp}:>240^{\circ} \mathrm{C}$ (decomp.); ${ }^{1} \mathrm{H}$ NMR (500 MHz, DMSO-d 6 ) $\delta$ (ppm) 11.67 (brs, 1H, NH/OH), 11.04 (s, $1 \mathrm{H}, \mathrm{NH} / \mathrm{OH}), 10.20$ (brs, $1 \mathrm{H}, \mathrm{NH} / \mathrm{OH}), 8.56$ (d, $J=8.5 \mathrm{~Hz}, 1 \mathrm{H}, \mathrm{C}[14]-\mathrm{H})$, $7.75(\mathrm{dd}, J=8.5 \mathrm{~Hz}, 2.5 \mathrm{~Hz}, 1 \mathrm{H}, \mathrm{C}[13]-\mathrm{H}), 7.70(\mathrm{~d}, J=7.5 \mathrm{~Hz}, 2 \mathrm{H}, \mathrm{C}[3]-$ $\mathrm{H}), 7.63(\mathrm{~d}, J=2.5 \mathrm{~Hz}, 1 \mathrm{H}, \mathrm{C}[11]-\mathrm{H}), 7.43(\mathrm{t}, J=7.5 \mathrm{~Hz}, 2 \mathrm{H}, \mathrm{C}[2]-\mathrm{H})$, $7.14(\mathrm{t}, J=7.5 \mathrm{~Hz}, 1 \mathrm{H}, \mathrm{C}[1]-\mathrm{H}), 6.77(\mathrm{~s}, 1 \mathrm{H}, \mathrm{C}[8]-\mathrm{H}) ;{ }^{13} \mathrm{C}$ NMR $(75 \mathrm{MHz}$, DMSO- $_{6}$ ) $\delta$ (ppm) 169.4, 156.2, 155.5, 146.7, 141.9, 137.9, 131.4, 129.5, 129.1, 123.7, 120.3, 114.2, 110.0, 106.8; HR-MS:(ESI) calcd. for $\mathrm{C}_{16} \mathrm{H}_{12} \mathrm{~N}_{4} \mathrm{O}_{4} 324.0859[\mathrm{M}+\mathrm{H}]^{+}$, found: 325.0942, Df. $=-3.36 \mathrm{ppm}$.

\section{Acknowledgements}

This project was supported by National Research, Development and Innovation Fund of Hungary, financed under the [2018-1.1.2KFI-2018-00097; 2018-1.3.1-VKE-2018-00032; OTKA PD128612] funding scheme. The authors are grateful for the Bolyai Research Scholarship of the Hungarian Academy of Sciences (BO/799/21/7) and the ÚNKP-21-5 new National Excellence Program of the Ministry for Innovation and Technology from the Source of the National Research, Development and Innovation Fund.

\section{Conflict of Interest}

The authors declare no conflict of interest.

Keywords: Fluorescence - GFP analogues - Stokes shift · Twophoton fluorescence

[1] R. Tsien, Annu. Rev. Biochem. 1998, 67, 509-544.

[2] G. Huang, J. Ho, C. Prabhakar, Y. Liu, S. Peng, Org. Lett. 2012, 14, 50345037.

[3] G. Cui, Z. Lan, W. Thiel, J. Am. Chem. Soc. 2012, 134, 1662-1672.

[4] Y. Chen, R. Sung, K. Sung, J. Phys. Chem. A 2018, 122, 5931-5944.

[5] Y. Chen, R. Sung, K. Sung, Org. Lett. 2018, 20, 1768-1772.

[6] W. Lo, Y. Chen, K. Sung, J. Org. Chem. 2013, 78, 5925-5931.

[7] Y. Chen, R. Sung, K. Sung, J. Lumin. 2019, 213, 446-450.

[8] Y. Chen, W. Lo, K. Sung, J. Org. Chem. 2013, 78, 301-310.

[9] J. Yang, G. Huang, Y. Liu, S. Peng, Chem. Commun. 2008, 1344-1346.

[10] A. A. Pakhomov, V. I. Martynov, Chem. Biol. 2008, 15, 755-764.
[11] J. W. Park, Y. M. Rhee, J. Am. Chem. Soc. 2016, 138, 13619-13629.

[12] L. M. Tolbert, A. Baldridge, J. Kowalik, K. M. Solntsev, Acc. Chem. Res. 2012, 45, 171-181.

[13] G. Huang, C. Lin, Y. Liu, S. Peng, J. Yang, Photochem. Photobiol. 2015, 4, 714-722.

[14] S. Tou, G. Huang, P. Chen, H. Chang, J. Tsai, J. Yang, Chem. Commun. 2014, 50, 620-622.

[15] M. Ormö, A. B. Cubitt, K. Kallio, L. A. Gross, R. Y. Tsien, S. J. Remingtont, Science 1996, 273, 1392-1395.

[16] R. Szostak, C. Liu, R. Lalancette, M. Szostak, J. Org. Chem. 2018, 83, $14676-14682$.

[17] Y. Guo, L. Yao, L. Luo, H.-X. Wang, Z. Yang, Z. Wang, S.-L. Ai, Y. Zhang, Q.-C. Zou, H.-L. Zhang, Org. Chem. Front. 2021, 8, 239-248.

[18] K. L. Keel, J. J. Tepe, Org. Chem. Front. 2020, 7, 3284-3311.

[19] C. L. Walker, K. A. Lukyanov, I. V. Yampolsky, A. S. Mishin, A. S. Bommarius, A. M. Duraj-Thatte, B. Azizi, L. M. Tolbert, K. M. Solntsev, Curr. Opin. Chem. Biol. 2015, 27, 64-74.

[20] L. Shi, Y. Li, Z.-P. Liu, T. D. James, Y.-T. Long, Talanta 2012, 100, 401-404.

[21] Y. Li, L. Shi, L.-X. Qin, L.-L. Qu, C. Jing, M. Lan, T. D. James, Y.-T. Long, Chem. Commun. 2011, 47, 4361-4363.

[22] S. Fery-Forgues, S. Veesler, W. B. Fellows, L. M. Tolbert, K. M. Solntsev, Langmuir 2013, 29, 14718-14727.

[23] Y. Zheng, G. Li, H. Deng, Y. Su, J. Liu, X. Zhu, Polym. Chem. 2014, 5, 2521-2529.

[24] L. Cai, H. Li, X. Yu, L. Wu, X. Wei, T. D. James, C. Huang, ACS Appl. Bio Mater. 2021, 4, 2128-2134.

[25] J. Riedl, P. Ménová, R. Pohl, P. Orság, M. Fojta, M. Hocek, J. Org. Chem. 2012, 77, 8287-8293.

[26] U. Wenge, H.-A. Wagenknecht, Synthesis 2011, 2011, 502-508.

[27] A. Y. Smirnov, M. M. Perfilov, E. R. Zaitseva, M. B. Zagudaylova, S. O. Zaitseva, A. S. Mishin, M. S. Baranov, Dyes Pigm. 2020, 177, 108258.

[28] L. Xu, J. Zhang, L. Yin, X. Long, W. Zhang, Q. Zhang, J. Mater. Chem. C 2020, 8, 6342-6349.

[29] T. B. Clark, M. Ziółkowski, G. C. Schatz, T. Goodson, J. Phys. Chem. B 2014, 118, 2351-2359.

[30] T. B. Clark, M. E. Orr, D. C. Flynn, T. Goodson, J. Phys. Chem. C 2011, 115, 7331-7338.

[31] A. Jancsó, E. Kovács, L. Cseri, B. J. Rózsa, G. Galbács, I. G. Csizmadia, Z Mucsi, Spectrochim. Acta Part A 2019, 218, 161-170.

[32] N. S. Baleeva, S. O. Zaitseva, D. A. Gorbachev, A. Y. Smirnov, M. B. Zagudaylova, M. S. Baranov, Eur. J. Org. Chem. 2017, 2017, 5219-5224.

[33] M. S. Baranov, K. M. Solntsev, N. S. Baleeva, A. S. Mishin, S. A. Lukyanov, K. A. Lukyanov, I. V. Yampolsky, Chem. A Eur. J. 2014, 20, 13234-13241.

[34] J. Yang, G. Huang, Y. Liu, S. Peng, Chem. Commun. 2008, 1344-1346.

[35] S. P. Laptenok, J. Conyard, P. C. B. Page, Y. Chan, M. You, S. R. Jaffrey, S. R. Meech, Chem. Sci. 2016, 7, 5747-5752.

[36] S. Chatterjee, K. Ahire, P. Karuso, J. Am. Chem. Soc. 2020, 142, 738-749.

[37] S. Gutiérrez, D. Martínez-López, M. Morón, D. Sucunza, D. Sampedro, A. Domingo, A. Salgado, J. J. Vaquero, Chem. A Eur. J. 2015, 21, 1875818763.

[38] I. N. Myasnyanko, A. S. Gavrikov, S. O. Zaitseva, A. Y. Smirnov, E. R. Zaitseva, A. I. Sokolov, K. K. Malyshevskaya, N. S. Baleeva, A. S. Mishin, M. S. Baranov, Chem. A Eur. J. 2021, 27, 3986-3990.

[39] M. Muselli, C. Baudequin, C. Perrio, C. Hoarau, L. Bischoff, Chem. A Eur. J. 2016, 22, 5520-5524.

[40] N. V. Povarova, S. O. Zaitseva, N. S. Baleeva, A. Y. Smirnov, I. N. Myasnyanko, M. B. Zagudaylova, N. G. Bozhanova, D. A. Gorbachev, K. K. Malyshevskaya, A. S. Gavrikov, A. S. Mishin, M. S. Baranov, Chem. A Eur. J. 2019, 25, 9592-9596.

[41] M. S. Garre, R. Losantos, S. Gutiérrez, D. Sucunza, P. Garc, S. Gutie, D. Sampedro, J. J. Vaquero, J. Org. Chem. 2020, 85, 441-448.

[42] T.P. Singh, T. J. Devi, N. P. Singh, O. M. Singh, ChemistrySelect 2018, 3, 6596-6600.

[43] A. I. Sokolov, I. N. Myasnyanko, N. S. Baleeva, M. S. Baranov, ChemistrySelect 2020, 5, 7000-7003.

[44] T. Chatterjee, M. Mandal, A. Das, K. Bhattacharyya, A. Datta, P. K. Mandal, J. Phys. Chem. B 2016, 120, 3503-3510.

[45] M. S. Baranov, K. M. Solntsev, K. A. Lukyanova, I. V. Yampolsky, Chem. Commun. 2013, 49, 5778-5780.

[46] A. Baldridge, J. Kowalik, L. M. Tolbert, Synthesis 2010, 2424-2436.

[47] J. B. Ekeley, A. R. Ronzio, J. Am. Chem. Soc. 1935, 57, 1353-1356.

[48] T. Chatterjee, D. Roy, A. Das, A. Ghosh, P. P. Bag, P. K. Mandal, RSC Adv. 2013, 3, 24021-24024.

[49] K.-Y. Chen, Y.-M. Cheng, C.-H. Lai, C.-C. Hsu, M.-L. Ho, G.-H. Lee, P.-T. Chou, J. Am. Chem. Soc. 2007, 129, 4534-4535. 
[50] W.-T. Chuang, C.-C. Hsieh, C.-H. Lai, C.-H. Lai, C.-W. Shih, K.-Y. Chen, W.Y. Hung, Y.-H. Hsu, P.-T. Chou, J. Org. Chem. 2011, 76, 8189-8202.

[51] J. Kang, G. Zhao, J. Xu, W. Yang, Chem. Commun. 2010, 46, 2868-2870.

[52] D. N. Shinde, R. Trivedi, N. Vamsi Krishna, L. Giribabu, B. Sridhar, B. B. Rathod, R. S. Prakasham, Appl. Organomet. Chem. 2018, 32, e4021.

[53] S. R. Samanta, J. P. Da Silva, A. Baldridge, L. M. Tolbert, V. Ramamurthy, Org. Lett. 2014, 16, 3304-3307.

[54] E. A. Dolgopolova, T. M. Moore, W. B. Fellows, M. D. Smith, N. B. Shustova, Dalton Trans. 2016, 45, 9884-9891.

[55] S. O. Zaitseva, S. V. Golodukhina, N. S. Baleeva, E. A. Levina, A. Y. Smirnov, M. B. Zagudaylova, M. S. Baranov, ChemistrySelect 2018, 3, 8593-8596.

[56] Y.-H. Hsu, Y.-A. Chen, H.-W. Tseng, Z. Zhang, J.-Y. Shen, W.-T. Chuang, T.C. Lin, C.-S. Lee, W.-Y. Hung, B.-C. Hong, S.-H. Liu, P.-T. Chou, J. Am. Chem. Soc. 2014, 136, 11805-11812.

[57] Z. Mucsi, A. Szabó, I. Hermecz, Á. Kucsman, I. G. Csizmadia, J. Am. Chem. Soc. 2005, 127, 7615-7631.

[58] R. Lakowicz Joseph, Principles of Fluorescence Spectroscopy, Springer, Boston, 2006, pp. 187-215.

[59] C.-C. Hsieh, P.-T. Chou, C.-W. Shih, W.-T. Chuang, M.-W. Chung, J. Lee, T. Joo, J. Am. Chem. Soc. 2011, 133, 2932-2943.

[60] M. Cigáň, J. Donovalová, V. Szöcs, J. Gašpar, K. Jakusová, A. Gáplovský, J. Phys. Chem. A 2013, 117, 4870-4883.

[61] W. Denk, J. H. Strickler, W. W. Webb, Science 1990, 248, 73-76.

[62] M. G. Vivas, L. De Boni, C. R. Mendonça, in Molecular and Laser Spectroscopy (Ed.: V. P. Gupta), Elsevier, 2018, pp. 165-191.

[63] L. Yuan, W. Lin, H. Chen, S. Zhu, L. He, Angew. Chem. Int. Ed. 2013, 52, 10018-10022; Angew. Chem. 2013, 125, 10202-10206.

[64] A. Nag, D. Goswami, J. Photochem. Photobiol. A 2009, 206, 188-197.

[65] C. Xu, W. W. Webb, J. Opt. Soc. Am. B 1996, 13, 481-491.
[66] N. S. Makarov, M. Drobizhev, A. Rebane, Opt. Express 2008, 16, 40294047.

[67] M. J. Frisch, G. W. Trucks, H. B. Schlegel, G. E. Scuseria, M. A. Robb, J. R. Cheeseman, G. Scalmani, V. Barone, B. Mennucci, G. A. Petersson, H. Nakatsuji, M. Caricato, X. Li, H. P. Hratchian, A. F. Izmaylov, J. Bloino, G. Zheng, J. L. Sonnenberg, M. Hada, M. Ehara, K. Toyota, R. Fukuda, J. Hasegawa, M. Ishida, T. Nakajima, Y. Honda, O. Kitao, H. Nakai, T. Vreven, J. A. Montgomery Jr., J. E. Peralta, F. Ogliaro, M. Bearpark, J. J. Heyd, E. Brothers, K. N. Kudin, V. N. Staroverov, R. Kobayashi, J. Normand, K. Raghavachari, A. Rendell, J. C. Burant, S. S. lyengar, J. Tomasi, M. Cossi, N. Rega, J. M. Millam, M. Klene, J. E. Knox, J. B. Cross, V. Bakken, C. Adamo, J. Jaramillo, R. Gomperts, R. E. Stratmann, O. Yazyev, A. J. Austin, R. Cammi, C. Pomelli, J. W. Ochterski, R. L. Martin, K. Morokuma, V. G. Zakrzewski, G. A. Voth, P. Salvador, J. J. Dannenberg, S. Dapprich, A. D. Daniels, Ö. Farkas, J. B. Foresman, J. V. Ortiz, J. Cioslowski, D. J. Fox, Gaussian Inc Wallingford CT 2016.

[68] V. Barone, M. Cossi, J. Phys. Chem. A 1998, 102, 1995-2001.

[69] E. Kovács, F. Faigl, Z. Mucsi, J. Org. Chem. 2020, 85, 11226-11239.

[70] B. Chiovini, D. Pálfi, M. Majoros, G. Juhász, G. Szalay, G. Katona, M. Szőri, O. Frigyesi, C. Lukácsné Haveland, G. Szabó, F. Erdélyi, Z. Máté, Z. Szadai, M. Madarász, M. Dékány, I. G. Csizmadia, E. Kovács, B. Rózsa, Z. Mucsi, ACS Omega 2021, 6, 15029-15045.

[71] É. Frank, Z. Mucsi, I. Zupkd', B. Réthy, G. Falkay, G. Schneider, J. Wölfling, J. Am. Chem. Soc. 2009, 131, 3894-3904.

Manuscript received: September 20, 2021

Revised manuscript received: October 13, 2021

Accepted manuscript online: October 15, 2021 